\title{
DOING BUSINESS THROUGH A PERMANENT ESTABLISHMENT (PE)
}

I. OPERATING THROUGH A PERMANENT ESTABLISHMENT

A. The tax PE threshold

B. The tests to determine the existence of a PE

1. The place of business and right of use tests

2. The location and duration tests

3. The business connection test

C. Building sites

D. Preparatory/auxiliary activities and the anti-fragmentation rule
E. The Agency-PE: functional analysis 1.48

F. Structures in shipping and air transport

II. FORCE OF ATTRACTION OF THE PE

A. Which activities are 'attracted' by the PE?

1.85

B. Separate treatment of isolated classes of income

III. PROTECTING THE PE OPERATION THROUGH THE NON-DISCRIMINATION CLAUSE

The perspective of the country of destination of the investment reveals important aspects of the BEPS impact on tax treaties, and notably that there are now new limitations to the avoidance of the PE status. Before 2017 one of the planning techniques was in fact for non-resident investors to carry out activities in the SC to avoid the so called 'PE status', avoiding the payment of taxes in the SC.

This chapter focuses on the new aspects of operating through a PE in the SC, by looking at the tax PE threshold, the tests to determine the existence of PE, and by discussing BEPS changes in respect to preparatory/auxiliary activities, the anti-fragmentation rule, and finally to structures in shipping and air transport (section I). The chapter also looks at more traditional treaty approaches to problems such as the force of attraction of the PE and the separate treatment of isolated classes of income, also discussing how to protect the $\mathrm{PE}$ operation through the non-discrimination clause (sections II-III). 


\section{OPERATING THROUGH A PERMANENT ESTABLISHMENT}

\section{A. The tax PE threshold}

1.03 The taxation of business profits within the treaty is organized in two main provisions: on the one hand, Art. 5 defines the concept of PE but does not itself allocate taxing rights, on the other hand, Art. 7 allocates taxing rights with respect to business profits of an enterprise of a CS attributable to a PE. Art. 7 is based on the separate entity and arm's length principles ${ }^{1}$ and has been subject to considerable variations in interpretation. Starting from a lack of a common interpretation, the 1984 report and the 1993 report 'Attribution of Income to PEs' eventually led in 2008 to the report 'Attribution of Profits to PEs' ('2008 Report'), and a new version of Art. 7 appeared in Model 2010, while a revised version of 2008 was adopted in 2010 ('2010 Report'). The current version of Art. 7 reflects the approach developed in the 2010 Report and must be interpreted in light of the guidance contained in it. ${ }^{2}$

1.04 Art. $7 \S 1$ provides that profits of an enterprise of a CS shall be taxable only in the $\mathrm{RC}$ unless the enterprise carries on business in the $\mathrm{SC}$ through a $\mathrm{PE}$ situated therein. If the enterprise carries on business as aforesaid, the profits that are attributable to the $\mathrm{PE}$ in accordance with Art. $7 \S 2$ may be taxed in the $\mathrm{SC}$ (Art. $7 \S 1)$. An additional problem is the non discrimination in the $\mathrm{SC}$ of PEs of foreign enterprises. The first principle established by Art. $7 \S 1$ is that there is extraterritorial tax jurisdiction of the $\mathrm{RC}$ in respect to business profits sourced in the $\mathrm{SC}$ only if there is a $\mathrm{PE}$ in the $\mathrm{SC}$ of a taxpayer resident of the RC producing such profits.

1.05 The Commentary remarks that there is international consensus on this principle: 'until an enterprise of one state has a PE in another state, it should

1 Commentary to Art. $7 \S 1-3$. The 2010 Report is divided into four parts: attribution of profits to PEs in general; PEs of banks; PEs of enterprises carrying on global trading; and PEs of enterprises carrying on insurance activities.

2 On this evolution see: Burgers, Irene, 'Commentary on Art. 7 of the OECD Model treaty' in: Burgers, Irene et al. (eds), The Taxation of Permanent Establishments (IBFD 1994); Gutman, Daniel, 'French Swiss Point of View on the Societe Schneider Electric Case: Some Thoughts on the Personal Attribution of Income Requirement in International Tax Law' (2003) 31 Intertax 156; IFA, 'The Attribution of Profits to Permanent Establishment' Cabiers Droit Fisc. Intl. (2006) 91b; Malherbe, Jacques, 'Permanent Establishments Claim their Share of Profits: Does the Taxman Agree?' (2011) 66 Bull. Intl. Tax. 359; Nouel, Luis, 'The New Art. 7 of the OECD Model Tax Convention: the End of the Road?' (2011) 65 Bull. Intl. Tax. 1; OECD, 2010 Report on the Attribution of Profits to Permanent Establishments (OECD 2010); Pijl, Hans, 'Morgan Stanley: Issues Regarding Permanent Establishment and Profit Attribution in Light of the OECD View' (2008) 62 Bull. Intl. Tax. 164; Pijl, Hans, 'Interpretation of Art. 7 of the OECD Model, Permanent Establishment Financing and Other Dealings' (2011) 65 Bull. Intl. Tax. 294; Russo, Roberto, The Attribution of Profits to Permanent Establishments: the Taxation of Intra-Company Dealings (IBFD 2005). 
not properly be regarded as participating in the economic life of that other state to such an extent that the other state should have taxing rights on its profits', adding that the right to tax of the state where the $\mathrm{PE}$ is situated does not extend to profits that an enterprise may derive from that state but that are not attributable to the PE. ${ }^{3}$ National courts affirm this principle. ${ }^{4}$

The second principle implicit to Art. $7 \S 1$ is that extraterritorial tax jurisdiction of the $\mathrm{RC}$ in respect of business profits sourced in the $\mathrm{SC}$ is limited to the profits 'attributable' to the $\mathrm{PE}$ in the $\mathrm{SC}$. This is a very broad concept that is now more precisely defined by Art. $7 \S 2$ introduced in 2010, which on the basis of the separate enterprise fiction, provides a method for attributing profits to a PE but courts had already established and applied this principle. ${ }^{5}$

Moreover, when a PE is deemed to exist, the clause of Art. $7 \S 1$, according to which taxation in the $\mathrm{SC}$ is limited to profits attributable to the $\mathrm{PE}$ in the SC, must be read in combination with Art. $7 \S 4$ which establishes that if profits include items of income which are dealt with separately in other articles of the Convention, then the provisions of those articles shall not be affected by the provisions of Art. 7. The Commentary notes that even when there is a $\mathrm{PE}$ in the SC, Art. $7 \S 1$ prevents the RC from taxing an enterprise of the other CS (the $\mathrm{SC}$ ) on profits that are not attributable to the PE: 'the right to tax of the state where the $\mathrm{PE}$ is situated does not extend to profits that the enterprise may derive from that state but that are not attributable to the PE'. ${ }^{6}$ So the determination of the profits attributable to the $\mathrm{PE}$ is then developed through the principle of separate taxation of isolated classes of income established by Art. $7 \S 4$ by using the concept of 'effectively connected income' within an approach defined as a 'restricted force of attraction' of the PE. Courts have developed that approach, first by defining the concept of foreign 'business profits' that become taxable in the SC, and second by addressing the issues posed by domestic CFC rules to such a principle.

Art. $7 \S 1$ refers to the "profits of an enterprise of a CS which may be taxable in the $\mathrm{SC}$ if the enterprise carries on business in the $\mathrm{SC}$ through a PE situated therein', and specifies that only the 'profits that are attributable to the $\mathrm{PE}$ ' in accordance with Art. $7 \S 2$ may be taxed in the SC. The Commentary notes that the term 'profits' has a broad meaning which includes all income derived in

3 Commentary to Art. $7 \S 11$.

4 Spain, Tribunal Economico Administrativo Central, 03852/2004, 23 November 2006.

5 Norway, Høyesterett, HR-2011-02245-A, (sak nr. 2011/755), 2 December 2011.

6 Commentary to Art. $7 \S 12$. 
carrying on an enterprise and corresponds to the use of the term made in domestic laws of most OECD Member Countries. ${ }^{7}$

1.09 Domestic laws often include so-called CFC rules under which the profits of a foreign enterprise (the controlled company) are attributed to the parent company (if certain requirements are met) even if they are not actually distributed as dividends. The result is that if the controlled company is resident of a CS and the parent company is in the other CS, the profits of the controlled company are taxed in the CS of the parent company even if the controlled company does not have a PE there, thereby conflicting with Art. $7 \S 1$, which provides that profits of an enterprise of a CS shall be taxable only in the $\mathrm{RC}$ unless the enterprise carries on business in the $\mathrm{SC}$ through a $\mathrm{PE}$ situated therein. ${ }^{8}$ An opposite approach is found in a case decided in Japan in which the court held that $\mathrm{CFC}$ rules did not violate the business profits article of the treaty. ${ }^{9}$ Brazil is a country that has very broad CFC legislation and this resulted in many important cases. ${ }^{10}$ The Commentary affirms now that CFC rules do not conflict with treaties. ${ }^{11}$

\section{B. The tests to determine the existence of a PE}

1.10 The main use of the concept of a $\mathrm{PE}$ as defined by treaties is to determine the right of a CS (the SC) to tax the profits of an enterprise of the other CS. In fact, once there is a PE in the SC, under Art. 7 such SC has the power to tax the profits of an enterprise of the other $\mathrm{CS}$ arising from activities carried out through a PE situated therein. By contrast, the SC does not have the power to tax the profits of an enterprise of the other CS unless it carries on its business through a PE situated therein.

1.11 Before 2000, the income from professional services and other activities of an independent character was regulated by Art. 14 which was eliminated from the Model in 2000. The underlying idea was that there are differences between the concept of PE used in Art. 5 and 7, and the concept of fixed base

7 Commentary to Art. 7 § 71; Australia, High Court of Australia, Thiel v. Federal Commissioner of Taxation, 22 August 1990; Brazil, Tribunal Regional Federal da 2a Região Rio de Janeiro, 2004.50.01.001354-5/ES, 16 March 2010, Brazil, Tribunal Regional Federal da 4a Região (2002.71.00.006530-5/RS), 4 June 2009.

8 France, Conseil d'État, Assemblee 232276, 28 June 2002.

9 Japan, Supreme Court, 2008 (Gyo-hi) 91, 29 October 2009.

10 Brazil, Conselho de Contribuintes 108-08.765, 23 March 2006, 6; Brazil, Primeira Câmara, 16327.000530/ 2005-28, 17/12/2008, Eagle Distribuidora de Bebidas S.A. v. National Treasury, 101-97.070, First Taxpayers Council (1st Chamber), 2008 ; Brazil, Supremo Tribunal Federal, DAU 2,588, 10 April 2013.

11 Commentary to Art. $7 \S 14$; Commentary to Art. $10 \S 37$. 
used in Art. 14 (independent personal services), with the result that the definition of $\mathrm{PE}$ is applicable to what previously constituted a fixed base. ${ }^{12}$

In 2017 important changes were made to Art. 5 of the Model (new $\$ 4.1$ modification of $\S \S 4,5$ and 6 as a result of the adoption of the Report on Action 7 of the BEPS Project. Therefore the Commentary was also modified significantly. The position of the Commentary is that some of these changes are for the application of conventions concluded before their adoption because they reflect the consensus of the OECD member countries, while parts of the Commentary related to the change of the Model are prospective only and do not affect the interpretation of treaties in which these provisions are not included.

A 'PE' is a fixed place of business, through which the business of an enterprise is wholly or partly carried on. So there are three requirements for a $\mathrm{PE}$ to exist which are determined through a set of tests:

1. the existence of a 'place of business' (place of business test and right of use test), i.e., a facility such as premises or, in certain instances, machinery or equipment;

2. the place of business must be 'fixed', i.e. it must be established at a distinct place with a certain degree of permanence (location test and duration test); and

3. the carrying on of the business of the enterprise through this fixed place of business (business connection test), i.e., personnel of the enterprise conduct the business of the enterprise in the state in which the fixed place is situated. ${ }^{13}$

12 Austria, Verwaltungsgerichtshof, 2000/15/0118, 18 March 2004; Canada, Federal Court of Appeal, Dudney v. Her Majesty the Queen, 24 February 2000.

13 On the concept of PE before the BEPS Project see in general: Arnold, Brian J., 'The Taxation of Income from Services and Tax Treaties: Cleaning Up the Mess' (2011) 65 Bull. Intl. Tax. 59; Brugger, Florian, and Plansky, Patrick (eds), Permanent Establishments in International and EU Tax Law (Linde 2011); De Vries, David, 'The Concept of Permanent Establishment: A Comparative Analysis of Tax Treaty and Domestic Tax Law' (2010) 38 Intertax 577; IFA, 'Is There a Permanent Establishment?' Cabiers Droit Fisc. Intl. (2009) 94a; IFA, 'The Development in Different Countries of the Concept of a Permanent Establishment' Cabiers Droit Fisc. Intl. (1967) 52; IFA, 'The Position of Permanent Establishments in National and International Fiscal Law' Cahiers Droit Fisc. Intl. (1957) 34a; Kobetsky, Michael, International Taxation of Permanent Establishments. Principles and Policy (Cambridge University Press 2011); Konnov, Oleg, Permanent Establishment in Tax Law (M3 Press 2002); Rawal, Radhakishan, The Taxation of Permanent Establishments - an International Perspective (Spiramus 2006); Reamer, Ekkehart, Permanent Establishments: A Domestic Taxation, Bilateral Tax Treaty and Prospective (Kluwer Law International 2014); Rust, Alexander, 'Situs Principle V. Permanent Establishment Principle in International Tax Law' (2002) 56 Bull. Intl. Fisc. Doc. 15; Sasseville, Jacques, 'Is There a Permanent Establishment? General Report' (2009) 94a Cabiers Droit Fisc. Intl; Skaar, Arvid, Permanent Establishment, Erosion of Tax Treaty Principle (Kluwer 1991). 


\section{The place of business and right of use tests}

1.14 The existence of a place of business is ascertained through the place of business test, which looks at whether the place is at the taxpayer's disposal (right of use test) often disregarding the legal right to use in favour of the analysis of the actual presence, and of course the place of business must be a place 'through which' actual activities are carried out.

1.15 A place of business is any premises, facilities or installations used for carrying on the business of the enterprise whether or not they are used exclusively for that purpose (place of business test), ${ }^{14}$ such as a pitch in a market place or a permanently used area in a customs depot, and in particular a PE that exists within the premises of another enterprise when a foreign enterprise has at its constant disposal certain premises or a part thereof owned by the other enterprise. This situation is ascertained through the right of use test. ${ }^{15}$ Quite often there is a place of business because activities are carried out within the premises of the recipients. ${ }^{16} \mathrm{~A}$ place of business can occur through 'virtual technological facilities'. ${ }^{17}$

1.16 The right of use test when applied in isolation (i.e., not bundled together with the permanence test) dictates that for a place of business to exist a certain amount of space must be at the disposal of the taxpayers, it being irrelevant whether premises, facilities or installations are owned, rented, or otherwise. ${ }^{18}$ When there is no actual right of use of the premises or facilities there is no place of business. ${ }^{19}$

1.17 The Commentary 2017 has clarified this concept: whether a location is at the disposal of an enterprise depends on that enterprise having the effective power

14 Commentary to Art. 5 § 10 .

15 Austria, Verwaltungsgerichtshof, 96/14/ 0084, 21 May 1997; Germany, Bundesfinanzhof, IR 80-81/91, 3 February 1993.

16 Germany, FinanzgerichtMünster 9K 6931/98, 6 November 2000.

17 India, Income Tax Appellate Tribunal Delhi, Amadeus Global Travel v. ADIT, 30 November 2007. In a wider sense this is the problem of taxing certain models of business of the digital economy, see for example: Hellerstein, Walter, 'Jurisdiction to Tax in the Digital Economy: Permanent and Other Establishments', (2014) 68 Bull. Intl. Tax. 6; IFA, 'Taxation of Income Derived from Electronic Commerce' Cahiers Droit Fisc. Intl. (2001) 86a; Schaffner, Jean, How Fixed Is a Permanent Establishment? (Kluwer Law International 2013).

18 India, Income Tax Appellate Tribunal (ITAT), Ericsson Radio Systems AB (EAB), Motorola Inc. (MI) and Nokia Networks OY (NOY) v. Deputy Commissioner of Income Tax, 22 June 2005, (2005) 96 TTJ Delhi; Austria, Verwaltungsgerichtshof, 2000/15/0118, 18 March 2004.

19 Commentary to Art. 5 \$ 12. See: Belgium, Rechtbank van EersteAanleg Luik, 9 December 2004; Germany, Bundesfinanzhof, IR 30/07, 4 June 2008; India, Income Tax Appellate Tribunal (ITAT), Ericsson Radio Systems $A B$ (EAB), Motorola Inc. (MI) and Nokia Networks OY (NOY) v. Deputy Commissioner of Income Tax, 22 June 2005. 
to use that location as well as the extent of the presence of the enterprise at that location and the activities that it performs there. This occurs if there is legal possession of the location, but also occurs when an enterprise is allowed to use a specific location that belongs to another enterprise or that is used by a number of enterprises and performs its business activities at that location on a continuous basis during an extended period of time. By contrast, the place is not at the disposal of an enterprise if the enterprise's presence at that location is intermittent or incidental (for example the carrying on of business activities at the home of an individual), or if an enterprise does not have a right to be present at a location. This occurs for example when a plant is owned and used exclusively by a contract-manufacturer. ${ }^{20}$

The right of use test often implies a multi-level analysis of the organization of the firm $^{21}$ as the mere presence of an enterprise at a particular location does not necessarily mean that location is at the disposal of that enterprise. ${ }^{22}$ The place of business must be a place 'through which' actual activities are carried out, and this includes any situation where business activities are carried on at a particular location at the disposal of the enterprise. ${ }^{23}$

\section{The location and duration tests}

Not only must a place of business exist and be effectively available (place of business test and right of use test), but must it must be 'fixed'. This concept of the 'fixed' place of business implies a location test that also looks at a commercial and geographic coherence for mobile activities, as well as a duration test in terms of a certain degree of permanency of the place of business. The location test focuses on the link between the place of business and a specific geographical point, in the sense that the equipment 'remains on a particular site' ('spatial delimitation approach,' but see $\$ 20$ of the Commentary), it being irrelevant that the place of business is actually fixed to the soil. ${ }^{24}$

Business activities carried on by an enterprise often move between neighbouring locations in the SC, so that a concept of commercial and geographic coherence should be used for those mobile activities. ${ }^{25}$ Examples of activities

20 Commentary to Art. $5 \S 12$ and 18.

21 Canada, Tax Court of Canada, Knights of Columbus v. Her Majesty the Queen, 16 May 2008.

22 Commentary to Art. $5 \S 11$, Commentary to Art. $5 \S 16$, Commentary to Art. $5 \S 12$.

23 Germany, Finanzgericht Baden-Württemberg 3K 309/91, 11 May 1992; The Netherlands, Gerechtshof sGravenhage, 101/82 MII, 28 March 1983.

24 Commentary to Art. 5 § 21; and § 122-126. See: The Netherlands, Rechtbank Breda, AWB09/563, 25 May 2009, 8; Norway, Norwegian Supreme Court, 15B/1984, 25 January 1984. See also: Schaffner, Jean, How Fixed Is a Permanent Establishment? (Kluwer Law International 2013).

25 Commentary to Art. $5 \S 23$. 
that amount to a 'fixed' place of business because they are coherent commercially and geographically are a very large mine, an 'office hotel', a consulting firm which regularly rents different offices, an outdoor market in parts of which a trader regularly sets up his stand. ${ }^{26}$ The Commentary also refers to activities based on revolving locations, such as a painter who, under a single contract, undertakes work throughout a building for a single client, or a consultant who moves from one office to another training the employees within the same branch location. ${ }^{27}$ There is a 'fixed' place of business when, for example, a painter works under a series of unrelated contracts for a number of unrelated clients in a large office building, or when a satellite is in geostationary orbit. ${ }^{28}$

1.21 The place of business to be 'fixed', must have a certain degree of permanency, and not be of a purely temporary nature. The rule of thumb here is that the place of business must last for at least six months. ${ }^{29}$ Commentary 2017 however introduces exceptions to this practice. The first exception is when activities are of a recurrent nature even if they extend over a number of years (for example drilling operations at a remote arctic location). The second exception is when activities constitute a business that was carried on exclusively in that country, possibly of short duration (for example the operation of a cafeteria during a four-month period in support to activities conducted in a remote place). ${ }^{30}$

1.22 It is also possible that a place of business exists for a very short period of time for activities of a recurrent nature, so that the duration of each period of time should be multiplied by the number of times. ${ }^{31} \mathrm{It}$ is however possible that the business carried on in a specific SC is short in terms of time but intense in terms of effective presence, so that the duration test is met. ${ }^{32}$

26 Norway, Tingrett Stavanger, 99-00421, 9 December 1999.

27 Commentary to Art. 5 § 25. See: Belgium, Rechtbank van EersteAanleg Luik, 9 December 2004; Norway, Høyesterett, 56/994, 10 June 1994.

28 Commentary to Art. 5 § 27.

29 Commentary to Art. 5 § 28. See: The Netherlands, Rechtbank Breda, AWB09/563, 25 May 2009; Norway, Høyesterett, 2004-01003-A, 8 June 2004.

30 Commentary to Art. 5 §§ 29-30.

31 Art. 4 § 4 of the Belgium-France treaty. See: Belgium, Rechtbank van EersteAanleg Gent, G1 2008/0446, 15 May 2008.

32 Commentary to Art. $5 \S 32$. See: Norway, Lagmannsrett Bergen, Scanwell AB and Mats Johanson v. Municipality of Stavanger, Gulating, 330-1989, 15 March 1991. 


\section{The business connection test}

A place of business to become a PE must exist and be effectively available (place of business test and right of use test), must be 'fixed' (location test), but also it must be a place of business 'through which' an enterprise carries on its business, a feature that is assessed by using the business connection test. The business connection test dictates that a place of business becomes a $\mathrm{PE}$ if the enterprise using it carries on (wholly or partly) its business activity through that place of business but on a regular basis, so that the fact that the place of business is actually productive or permanent is not a feature required to meet the business connection test. ${ }^{33}$

Leasing activities pose a business connection problem in so far as the lessor of leasing equipment to the lessee continues to operate it within the premises of the lessee on a regular basis with its own personnel. The Commentary indicates that leasing activities may lead to the fixed place of business qualifying as a PE depending: (i) on whether the lessor supplies personnel after installation to operate the equipment under its responsibility; and (ii) on whether the fixed place of business (constituted by the leased facilities, industrial, commercial or scientific equipment, buildings, or intellectual property) is under the control of lessor. ${ }^{34}$

So a fixed place of business is not a PE if facilities, industrial, commercial or scientific equipment, buildings, or intellectual property leased to third parties through a fixed place of business are not maintained by an enterprise in the $\mathrm{SC}$, and the contract is limited to the mere leasing even if the lessor supplies personnel after installation to operate the equipment, provided that their responsibility is limited solely to the operation/maintenance of the equipment. ${ }^{35}$, if a telecommunications operator in the $\mathrm{RC}$ enters into a 'roaming' agreement with an operator in the $\mathrm{SC}$ to allow its users in the $\mathrm{RC}$ to connect to the SC operator's telecommunications network, any place of the network in the $\mathrm{SC}$ is not at the disposal of operator in the RC. ${ }^{36}$ The ongoing delivery of spare parts by the seller or producer poses a problem similar to that posed by the leasing of equipment. According to the Commentary there is a PE in these cases if the enterprise maintains a fixed place of business for delivery of spare parts or maintains or repairs machinery, while there is no PE if the fixed place

33 Germany, Finanzgericht Baden-Württemberg 3K 309/91, 11 May 1992, 4; Canada, Tax Court of Canada, Knights of Columbus v. Her Majesty the Queen, 16 May 2008.

34 Commentary to Art. 5 §§ 36-37. See: Norway, Høyesterett RT 1997 s 653, 29 April 1997.

35 With regard to the leasing of containers report 'The Taxation of Income Derived from the Leasing of Containers' (OECD 1983).

36 Commentary to Art. $5 \S 38$. 
of business furnishes plans, etc. especially developed for the purposes of the individual customer. ${ }^{37}$

1.26 Gaming/vending machines and technological infrastructures such as cables and pipelines also pose a business connection problem in so far as the owner of that equipment operates it automatically and 'on remote'. Gaming and vending machines do not constitute a $\mathrm{PE}$ if the enterprise merely sets up the machines and then leases them to other enterprises, while they will constitute a $\mathrm{PE}$ if the enterprise which sets up the machines then operates and maintains them for its own account or through a dependent agent. ${ }^{38} \mathrm{~A}$ similar problem is posed by cables/pipelines, which, like vending machines, can be operated remotely and automatically. There is a PE (so the exclusion does not apply) if facilities, such as cables or pipelines, are used to transport property belonging to other enterprises. By contrast there is no PE if the enterprise transports its own property and the transport is merely incidental to the business of enterprise. ${ }^{39}$

1.27 The Commentary 2017 has not changed the traditional approach to the place of business test and right of use test but has made clarifications for subcontractors, remote operation, and joint ventures. The business connection test is met when an enterprise carries on its business through subcontractors at a fixed place of business that is at the disposal of the enterprise. In the absence of employees of the enterprise, other factors show that the enterprise clearly has the effective power to use that site, because the enterprise owns or has legal possession of that site and controls access to and use of the site, for example an enterprise that owns a small hotel and rents out the hotel's rooms through the Internet and has subcontracted the on-site operation of the hotel to a company remunerated on a cost-plus basis. Finally in a 'joint venture' in which different enterprises agree to each carry on a separate part of the same project generally a separate enterprise for the purposes of Artt. 3, 5 and 7 is not established and therefore the business connection test is not met. ${ }^{40}$

37 Commentary to Art. 5 § 71 .

38 Commentary to Art. 5 § 9 .

39 Commentary to Art. 5 § 64. See: Germany, Bundesfinanzhof, IIR 12/92, 30 October 1996.

40 Commentary to Art. $5 \S \S 40-44$. 


\section{Building sites}

Art. $5 \S 2$ provides a non-exhaustive list of examples of $\mathrm{PEs}^{41}$ which must be interpreted in the light of the general definition of $\mathrm{PE}$. Thus, there is a strict connection between Art. $5 \S 1$ and Art. $5 \S 2$ because a PE can exist in the form of one of the listed examples only if all the requirements of the basic-rule $\mathrm{PE}$ definition are satisfied. ${ }^{42} \mathrm{~A}$ 'place of management' is another positive example of Art. $5 \S 2.43 \mathrm{~A}$ 'place of management' is not necessarily an 'office' in the traditional sense, as it is sufficient that facilities are available in a coordinated way for conducting business. ${ }^{44}$ Even within such a concept of 'place of management' a minimal threshold is required for a $\mathrm{PE}$ to exist. ${ }^{45}$ Certain treaties contain a clause according to which 'substantial equipment' in the SC may amount to a PE. ${ }^{46}$ Moreover according to Art. $5 \S 3$ of the Model a building site or construction or installation project constitutes a $\mathrm{PE}$ only if it lasts more than 12 months.

This simple definition is analysed in the Commentary through five main issues: the concept of 'building site' or 'construction or installation project'; the 12-month test; how to treat preparatory works; interruptions and time spent by subsidiary-contractors; and finally projects undertaken by fiscally transparent partnerships.

A 'building site' or a 'construction or installation project' involves the construction or renovation of buildings, roads, as well as the laying of pipe-lines and excavations. ${ }^{47}$ The rationale of the 12 -month test is to establish a workable de minimis rule. ${ }^{48}$ The Commentary clarifies that the 12-month test applies to each individual site or project. ${ }^{49} \mathrm{~A}$ 'coherent whole commercially and geographically' occurs even if the work is based on several contracts and the orders

41 Commentary to Art. $5 \S 45$. The Commentary to Art. 5 at $\S 47-48$ acknowledges that there is no common view about mines, oil or gas wells, quarries or any other place of extraction of natural resources, all places of extraction of hydrocarbons whether on or off-shore, and exploration of natural resources.

42 Switzerland, Verwaltungsgericht Zürich (Administrative Court, Zürich), A 00 131, 28 August 2000, Luzerner Gerichts- und Verwaltungsentscheide, 2000, II, 25.

43 Commentary to Art. 5 § 24, 2-3. See: Canada, Supreme Court of Canada, Crown Forest Industries Ltd. v. Her Majesty the Queen, 22 June 1995, [1995] 2 C.T.C. 64; The Netherlands, Hoge Raad der Nederlanden 21.286, 24 November 1982. See: Ward, David, 'A Resident of a CS for Tax Treaty Purposes: A Case Comment on Crown Forest Industries' (1996) 44 Canadian Tax J. 408.

44 Commentary to Art. 5 § 46. See: Germany, Bundesfinanzhof (), I B 101/98, 17 December 1998; Norway, Lagmannsrett Hamar (), 91-01618 A, 16 June 1992.

45 Canada, Tax Court of Canada, Fiebert v. Her Majesty the Queen, 25 November 1985, [1986] 1 C.T.C. 2034.

46 Art. $4 \S 3$ b) of the treaty. See: Australia, Federal Court of Australia, Mcdermott Industries v. Commissioner of Taxation of the Commonwealth of Australia, 29 April 2005.

47 Commentary to Art. 5 § 50. See: Denmark, Landsskatteretten LSR 641-1220-1, 24 June 1996.

48 The Netherlands, Hoge Raad der Nederlanden, 32709, 9 December 1998.

49 Commentary to Art. $5 \S 51$. 
are placed by several persons. This approach is meant to counteract abuses in which enterprises divide their contracts up into several parts, each covering a period less than 12 months and attributed to a different company which is, however, owned by the same group. ${ }^{50}$ The 'aggregate approach' is supported by tax authorities but Courts often reject it. The typical situation is one in which several building projects, each lasting less than the treaty threshold (usually nine or 12 months), are carried out in the SC for the same customer, but under different contracts. ${ }^{51}$

1.31 The 12-month test becomes quite relevant with the presence of subcontractors, that is when an enterprise (general contractor) in a comprehensive project subcontracts parts of that project to other enterprises (subcontractors), the period spent by a subcontractor working on the building site must be considered as time spent by the general contractor and the subcontractor has a $\mathrm{PE}$ at the site if it lasts more than 12 months. Commentary 2017 also clarifies with an example how the 12-month test is applied when fiscally transparent partnerships undertake projects at the level of the partnership, with the result that each partner has a PE regardless of the time each has spent on the site.

1.32 The splitting-up of contracts is a potential strategy for the artificial avoidance of PE status. There is no significant modification in the Model 2017 about this issue, but the Commentary 2017 states that Art. 29 addresses this situation, or alternatively CSs should introduce a special provision. This proposed rule provides that where an enterprise of a CS carries on activities in the other CS at a place that constitutes a building site, construction project, installation project or other specific project, or carries on supervisory or consultancy activities in connection with such a place, and these activities are carried on during one or more periods of time that, in the aggregate, exceed 30 days; and where connected activities are carried on in that other CS at the same building site, construction or installation project, each exceeding 30 days, by one or more enterprises closely related to the first-mentioned enterprise, then these different periods of time are added to the aggregate period of time during which the first-mentioned enterprise has carried on activities at that building site, construction or installation project. This provision is also found in Art. 14 of the MLI.

1.33 The Commentary 2017 clarifies that the determination of whether activities are connected depends on the facts and circumstances of each case, relying on

50 France, Conseil d'État, 16095, 29 June 1981; Germany, Bundesfinanzhof I R 99/97, 21 April 1999.

51 Belgium, Hof van Beroep Antwerpen 1982-07-29, 29 June 1982; Belgium, Hof van Beroep Antwerpen, 1984-04-12, 12 April 1984; Norway, Tingrett Stavanger, 00-260A, 18 September 1980. 
key questions, such as whether: the contracts covering the different activities were concluded with the same person or related persons; the conclusion of additional contracts with a person is a logical consequence of a previous contract concluded with that person or related persons; the activities would have been covered by a single contract absent tax planning considerations; the nature of the work involved under the different contracts is the same or similar; the same employees are performing the activities under the different contracts. ${ }^{52}$

A site begins to exist on the date when the contractor begins preparatory work in the SC, and continues to exist until work is completed or abandoned or temporarily discontinued and that interruptions do not count (seasonal or other temporary interruptions should be included in determining the life of a site). ${ }^{53}$ This practical rule is in a different form than that generally adopted to determine when a PE begins to exist. That rule dictates that this happens when the enterprise commences carrying on its business through a fixed place of business, so the period of time during which the fixed place of business itself is being set up is not counted. By contrast a PE ceases to exist when it is disposed of, when activities are discontinued. If a fixed place of business is leased to another enterprise, the lessor's PE ceases to exist, except where the lessor continues carrying on a business activity of its own through the fixed place of business. ${ }^{54}$

\section{Preparatory/auxiliary activities and the anti-fragmentation rule}

Activities of multinational groups are often a seamless range of functions in which integrated services are performed. So it is difficult to distinguish the 'core' between other functions that are somehow related to core function. The problem here is to identify the threshold between those functions which constitute a PE and those which do not. Art. $5 \S 4$ lists a number of activities which are not PEs, even if the activity is carried on through a fixed place of business. The common feature of those activities is that the enterprise of the $\mathrm{RC}$ cannot, in principle, be taxed in the SC, if it carries on preparatory or auxiliary activities, i.e., activities that are not directly productive and do not belong to the core business of that enterprise. This list must be read in connection with Art. $5 \S 4 \mathrm{f}$ ) together with the final statement which operates as a residual clause and has been introduced by Model 2017 (see

54 Commentary to Art. 5 § 44. See: France, Conseil d'État, 16095, 29 June 1981; Austria, Verwaltungsgerichtshof), 2004/15/0001, 22 April 2009. 
below). ${ }^{55}$ Under the exception provided by Art. $5 \S 4$, activities carried out through a fixed place of business are not PEs if these activities are 'remote' from the actual realization of profits, so this approach has also been extended to more complex activities. 56 The Commentary to Art. $5 \S 130$ discusses in detail the core functions of enterprise in e-commerce.

1.36 Under the language adopted by Art. $5 \S 4 \mathrm{f}$ ) before the changes made by Model 2017 the combination of preparatory or auxiliary activities did not mean of itself that a PE existed. So an enterprise could fragment a cohesive operating business into several small operations to argue that each was merely engaged in preparatory or auxiliary activities. More specifically Art. $5 \S 4$ letters a)-e) provided that the term 'PE' did not include: a) the use of facilities solely for the purpose of storage, display or delivery of goods or merchandise belonging to the enterprise; b) the maintenance of a stock of goods or merchandise belonging to the enterprise solely for the purpose of storage, display or delivery; c) the maintenance of a stock of goods or merchandise belonging to the enterprise solely for the purpose of processing by another enterprise; d) the maintenance of a fixed place of business solely for the purpose of purchasing goods or merchandise or of collecting information, for the enterprise; and e) maintenance of a fixed place of business solely for the purpose of carrying on, for the enterprise, any other activity of a preparatory or auxiliary character.

1.37 So Art. $5 \S 4$ listed several exceptions to the basic PE rule of Art. 5 \$ 1, each of them serving a specific purpose, for example usually storage space fell under the exception of Art. $5 \S 3$ a). ${ }^{57}$ To address that issue the Commentary affirmed that several fixed places of business in the SC carrying out preparatory or auxiliary activities did not amount to a PE if they were separated organizationally', i.e., if each place of business operated in isolation. By contrast, those fixed places of business were deemed not to be 'separated organizationally' (and amounted to a PE) if each place of business performed complementary functions, such as receiving and storing goods in one place, distributing those goods through another, etc. ${ }^{58}$ Moreover a fixed place of

55 Belgium, Hof van Beroep Gent) 2004-11-30, 30 November 2004; India, Delhi High Court, UAE Exchange Centre Ltd v. Union of India, 13 February 2009.

56 India, Indian Supreme Court, Morgan Stanley E Co., United States v. Commissioner of Income Tax, 9 July 2007; Switzerland, Bundesgericht/Tribunal fédéral), 102 ATF 264, 17 September 1977.

57 Belgium, Hof van Beroep Gent 2005/AR/477, 16 January 2007; Belgium, Hof van Beroep Gent, 2002-06-18, 18 June 2002, Jurisprudence Fiscale, 2003; Denmark, Landsskatteretten, 1988-4-564, 15 December 1988.

58 Commentary to Art. $5 \S 74$, which has been eliminated in Commentary 2017. 
business used for preparatory or auxiliary activities and other activities was a single $\mathrm{PE}$ and taxable as regards both types of activities. ${ }^{59}$

Art. $5 \$ 4$ of the Model 2017 has now modified this approach with a more restrictive rule because the work on Action 7 led to changes to the wording of Art. $5 \S 4$ of the Model to address situations in which the specific activity exemptions give rise to BEPS concerns. ${ }^{60}$ Art. 13 of the MLI is very similar, but includes two options $A$ and $B$ and the latter differs from Art. $5 \S 4$ of the Model 2017. Letters a)-f) are substantially the same as before (the reference of preparatory and auxiliary activities has been taken out in individual letters) so that those exclusions continue to operate, but a final statement has been added which clarifies that the term 'PE' shall be deemed not to include each of the individual activities listed in letters a)-e) provided that each of those activities is of a preparatory or auxiliary character.

This final statement also clarifies that the maintenance of a fixed place of business solely for any combination of activities mentioned in subparagraphs a)-e), is not a PE if the overall activity of the fixed place of business is of a preparatory or auxiliary character. This implies that one not only has to conduct an analysis of each individual activity to check whether it is indeed of a preparatory or auxiliary nature, but also to develop an holistic approach of all the different places of business to determine whether, in their synergy, they effectively are just of a preparatory or auxiliary character.

The Model 2017 reflects a restrictive judicial trend which had previously denied, even under the pre-2017 language of Art. $5 \$ 4$, for example, that storage space as such constituted an exception. ${ }^{61}$ Another example of a PE was a company resident of the US which established a representative office in India to purchase materials from India, Egypt and Bangladesh, ${ }^{62}$ while another case took a different view. ${ }^{63}$ The collecting of information has also been considered to be a preparatory activity because information flows create a

59 The Netherlands, Hoge Raad der Nederlanden, 17.812, 24 March 1976.

60 On Action 7 BEPS Project: Dos Santos, António Carlos and Cidália Mota Lopes, 'Tax Sovereignty, Tax Competition and the Base Erosion and Profit Shifting Concept of Permanent Establishment' (2016) 25 EC Tax Review, 296; Storck, Alfred and Mechtler, Lukas, 'Permanent Establishment: Proposals Related to Art. 5(3) and (4) of the OECD Model Convention' in: Lang, Michael, et al., (eds) Base Erosion and Profit Shifting (BEPS), (Linde 2016) p. 57.

61 Spain, Tribunal Económico Administrativo Central, 0657/2003, 2 March 2003; Belgium, Hof van Beroep Gent, 2005/AR/477, 16 January 2007; Germany, Finanzgericht, II 1224/97, 6 September 2001.

62 India, Authority for Advance Rulings (AAR), Columbia Sportswear Company v. DIT, 8 August.

63 India, Income Tax Appellate Tribunal (ITAT) Mumbai, M. Fabrikant and Sons Inc. v. DIT, 31 March 2011. 
PE. ${ }^{64}$ This approach was confirmed by other judicial decisions dealing with the management of information in a broad sense. ${ }^{65}$

1.41 The restrictive judicial trend by national courts was also to consider that the preparatory or auxiliary natures of activities carried on through a fixed place of business are, in any event, within the core of a complex structure of transnational business. There were different judicial patterns in that respect. One approach was simply to consider preparatory activities as belonging to the core business. ${ }^{66}$ Moreover, according to the 'attraction approach', a place of business that in a broad sense supported a core business activity was deemed to be a PE. ${ }^{67}$ The criterion to decide whether preparatory or auxiliary activities of a fixed place of business are a PE traditionally was the fact that they formed an essential or significant part of the activity of enterprise 'as a whole', ${ }^{68}$ and that it could be relevant how 'remote' an activity is from the actual realization of profits. ${ }^{69}$ Even before 2017 the Commentary focused on the residual clause of Art. $5 \S 4 \mathrm{e}$ ) and pointed out that a fixed place of business through which the enterprise exercises solely an activity which has for the enterprise a preparatory or auxiliary character is deemed not to be a PE. ${ }^{70}$

1.42 The Commentary modified in 2017 with respect to these different situations clarifies with more precision the requirement for exemption from the status of PE. For example a stock of goods or merchandise belonging to an enterprise maintained by another person in facilities operated by that other person is not a $\mathrm{PE}$ when that enterprise does not have the facilities at its disposal. ${ }^{71} \mathrm{~A}$ bonded warehouse with special gas facilities that an exporter of fruit from one state maintains in another state for the sole purpose of storing fruit in a controlled environment during the customs clearance process in that other state also is not a PE. Likewise a fixed place of business that an enterprise

64 Germany, Bundesfinanzhof IR 292/81, 23 January 1985, Bundessteuerblatt, 1985, II, 13, 417 contra: Belgium, Hof van Beroep Gent 2004-11-30, 30 November 2004.

65 India, Income Tax Appellate Tribunal (ITAT) Delhi, Pioneer Overseas Corporation v. ADIT, Nos. 1868, 1869, 1870 and 1871/Del/2005, 24 December 2009; Italy, Corte Suprema di Cassazione, 7682, 25 May 2002; Germany, Bundesfinanzhof, IR 292/81, 23 January 1985; India, Income Tax Appellate Tribunal Delhi, Amadeus Global Travel v. ADIT, 30 November 2007; Germany, Finanzgericht II 1224/97, 6 September 2001; contra: Belgium, Hof van Beroep Gent 2004-11-30, 30 November 2004.

66 Austria, Verwaltungsgerichtshof, 98/14/0026, 19 March 2002.

67 Germany, Bundesfinanzhof, IR 130/83, 18 December 1986.

68 Commentary to Art. 5 § 59 .

69 Commentary to Art. 5 23, which has been eliminated in Commentary 2017 and transposed in other paragraphs.

70 Ibid.

71 Commentary to Art. $5 \S 65$. 
maintains solely for the delivery of spare parts to customers for machinery sold to those customers is not a PE. ${ }^{72}$

Subparagraph c) covers the situation in which a stock of goods or merchandise belonging to one enterprise is processed by a second enterprise, on behalf of, or on the account of, the first-mentioned enterprise. So situations of tollmanufacturers when a stock of goods belonging to an enterprise of the $\mathrm{RC}$ is maintained by a toll-manufacturer located in the SC for the purposes of processing are not PEs, unless the foreign enterprise is allowed unlimited access to the facilities of the toll-manufacturer for inspecting. The mere maintenance of a stock of goods for the purposes of processing by another enterprise is not a PE. By contrast, a fixed place of business used for the purchase of goods or merchandise where the overall activity of the enterprise consists in selling these goods and where purchasing is a core function of the business of the enterprise is a PE. ${ }^{73}$

The second part of subparagraph d) refers to the maintenance of a fixed place of business solely for the purpose of collecting information, so it is necessary to determine whether the collection of this information goes beyond the preparatory or auxiliary threshold: for example an office established by an investment fund solely to collect information of investment opportunities is not a PE. By contrast, a fixed place of business used to furnish plans etc. specially developed for the purposes of the individual customer is a PE. ${ }^{74}$

Subparagraph e) provides that a fixed place of business maintained solely for the purpose of carrying on, for the enterprise, any activity that is not expressly listed in subparagraphs a)-d) is not a PE if that activity is of a preparatory or auxiliary character. Examples of places of business covered by subparagraph e) are fixed places of business used solely for the purpose of advertising or for the supply of information or for scientific research or for the servicing of a patent or a know-how contract, if such activities have a preparatory or auxiliary character. By contrast, there is a PE if the fixed place of business used for the supply of information also furnishes plans, etc. specially developed for the purposes of the individual customer, or if a research establishment carries out actual manufacturing. There is also a PE if an enterprise that sells goods worldwide establishes an office in a state and the employees working at that office take an active part in the negotiation of important parts of contracts for 
the sale of goods to buyers in that state without habitually concluding contracts or playing the principal role leading to the conclusion of contracts (e.g., by participating in decisions related to the type, quality or quantity of products covered by these contracts). ${ }^{75}$

1.46 Art. 5 § 4.1. of the Model 2017 also introduced a so called 'anti-fragmentation rule'. Art. 13 MLI contains a similar rule. The purpose of Art. $5 \S 4.1$ is to prevent an enterprise or a group of closely related enterprises from fragmenting a cohesive business operation into several small operations in order to argue that each is merely engaged in a preparatory or auxiliary activity. Under Art. $5 \S 4.1$, the exceptions provided for by Art. $5 \S 4$ do not apply to a place of business that would otherwise constitute a PE where the activities carried on at that place and other activities of the same enterprise or of closely related enterprises exercised at that place or at another place in the same state constitute 'complementary functions that are part of a cohesive business operation'.

1.47 So there are two situations covered by Art. $5 \S 4$.1. in which the exemptions listed by Art. $5 \S 4$ do not apply. The first situation is the following: a fixed place of business is used or maintained by an enterprise when the same enterprise or a closely related enterprise carries on business activities at the same place or at another place in the same CS, if that place or other place constitutes a $\mathrm{PE}$ for the enterprise or the closely related enterprise under the provisions of Art. 5. The second situation is the following: a fixed place of business is used or maintained by an enterprise if the same enterprise or a closely related enterprise carries on business activities at the same place or at another place in the same CS, if the overall activity resulting from the combination of the activities carried on by the two enterprises at the same place, or by the same enterprise or closely related enterprises at the two places, is not of a preparatory or auxiliary character. In both situations, in order to have a $\mathrm{PE}$ the business activities carried on by the two enterprises at the same place, or by the same enterprise or closely related enterprises at the two places, must constitute 'complementary functions that are part of a cohesive business operation'. Art. $5 \S 8$ explains the meaning of the concept of a person or enterprise 'closely related to an enterprise' for the purposes of Art. $5 \S 4.1$.

\section{E. The Agency-PE: functional analysis}

1.48 The purpose of Art. $5 \S 5$ is to address those situations in which an enterprise does not have a fixed place of business in the SC within the meaning of Art. 5 
$\S \S 1$ and 2, and yet that enterprise should be treated as having a PE in that country if a person is acting for it in that country and, at the same time, certain requirements are met ('agency-PE'). ${ }^{76}$ The re-characterization of a certain situation as an agency-PE covers all actions of a 'dependent agent' for the principal, 77 and if there is a material $\mathrm{PE}$ there is no need to conduct the agency-PE test. ${ }^{78}$ The Commentary to Art. $5 \S 131$ addresses the general issue of whether the Internet service provider is a dependent agent.

The Model 2017 introduced significant changes to Art. $5 \S 5$ which imply a different approach from the past. Before these changes, the traditional approach under the previous Art. $5 \S 5$ was that the definition of 'dependent agent' was a negative one: dependent agents were persons who were not independent agents falling under Art. $5 \S 6$, who involved the enterprise to a particular extent in business activities in the $\mathrm{SC}$ in view of the scope of their authority or the nature of their activity, ${ }^{79}$ bearing in mind that only persons having the authority to conclude contracts repeatedly and not merely in isolated cases could lead to a PE authority. ${ }^{80}$

Under that analysis - which is maintained but expanded now by Model 2017 an agent having the 'authority to conclude contracts in the name of the enterprise' is a person who enters into contracts which are binding on the enterprise, even if those contracts are not actually in the name of the enterprise. Previous Commentary to Art. $5 \S 32$ indicated that the phrase 'authority to conclude contracts in the name of the enterprise' was not limited to contracts literally in the name of the enterprise but extended to contracts 'binding' on the enterprise even if those contracts were not actually in the name of the enterprise, clarifying that an agent could possess actual authority to conclude contracts if he solicited and received (but did not formally finalize) orders which were sent directly to a warehouse from which goods are delivered and where the foreign enterprise routinely approved the transactions. ${ }^{81}$

This substantial approach was quite minimal, but judicial cases have expanded

it, for example stating that the lack of active involvement by an enterprise in transactions may be indicative of a grant of authority to an agent when, for example, the agent solicits and receives (but does not formally finalize) orders

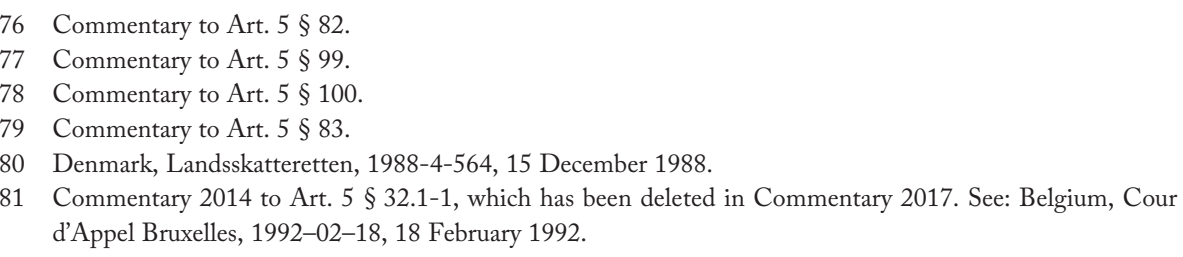

81 Commentary 2014 to Art. 5 \$32.1-1, which has been deleted in Commentary 2017. See: Belgium, Cour d'Appel Bruxelles, 1992-02-18, 18 February 1992. 
and the enterprise routinely approves the transactions, ${ }^{82}$ or clarifying that the activity of an agent who exercises authority to conclude contracts 'habitually' is more than 'merely transitory' and depends on the nature of contracts or business. ${ }^{83}$ The authority to conclude contracts must cover contracts relating to operations that constitute the business proper of the enterprise. Therefore, the authority of a person to engage employees for the enterprise, or to conclude contracts relating to internal operations only, is irrelevant.

1.52 As mentioned, the authority to conclude contracts has to be habitually exercised in the SC, and it is deemed that a person is authorized to negotiate a contract in a way binding on the enterprise, in spite of the fact that the contract is formally signed by another person, or in spite of the fact that such negotiating person has no power of representation. So in commercial practice the issue arose of what was exactly the impact of participation by the foreign enterprise in the negotiation of contracts. The Commentary observes that the mere fact that a person has attended or participated in negotiations is not, by itself, authority to conclude contracts because the relevant factor is determining the exact functions performed by that person on behalf of the enterprise. This concept was applied in an Indian case. ${ }^{84}$ National tax authorities have, however, adopted a restrictive approach and claimed that persons who have attended or participated in negotiations may constitute an agency-PE. ${ }^{85}$

1.53 Art. $5 \S 5$ as amended in Model 2017 expands significantly the pre-existing approach of the 'authority to conclude contracts' and adopts now a view that looks beyond that traditional analysis in so far as it adopts a functional approach based on a three-pronged test. Art. 13 MLI contains a similar rule. The work on Action 7 led to these changes to the wording of Art. $5 \S 5$ mainly to address the artificial avoidance of $\mathrm{PE}$ status through commissionnaire arrangements and similar strategies. ${ }^{86}$ Pursuant to Art. $5 \S 5$, where a person is acting in a CS on behalf of an enterprise and has, and habitually exercises, in a CS, an authority to conclude contracts, in doing so, habitually concludes

82 Russia, Federal Arbitration Court, N A40-58575/11-129-248, 2 August 2012.

83 Commentary to Art. 5 § 98. See: Germany, Bundesfinanzhof, I R 87/04, 3 August 2005.

84 Commentary to Art. 5 § 97. India, Income Tax Appellate Tribunal (ITAT) Delhi, Rolls Royce plc. v. ADIT, 19 April 2005.

85 See: Italy, Corte Suprema di Cassazione, 7682, 25 May 2002, Italy, Corte Suprema di Cassazione, 8488, 9 April 2010.

86 On the agency-PE Action 7 BEPS Project: Eisenbeiss, Justus, 'BEPS Action 7: Evaluation of the Agency Permanent Establishment', (2016) 44 Intertax 481; Pleijsier, Arthur, 'The Agency Permanent Establishment in BEPS Action 7: Treaty Abuse or Business Abuse?', (2015) 43 Intertax 147-54, etc.; Uslu, Yasin, 'An Analysis of 'Google Taxes' in the Context of Action 7 of the OECD/G20 Base Erosion and Profit Shifting Initiative', (2018) 72 Bull. Intl. Taxn. 
contracts, or habitually plays the principal role leading to the conclusion of contracts that are routinely concluded without material modification by the enterprise, and these contracts are a) in the name of the enterprise, or b) for the transfer of the ownership of, or for the granting of the right to use, property owned by that enterprise or that the enterprise has the right to use, or c) for the provision of services by that enterprise, that enterprise shall be deemed to have a $\mathrm{PE}$ in that state in respect of any activities which that person undertakes for the enterprise.

Even if the three-pronged test is not met the foreign enterprise is not deemed to have a PE if the activities of such a person are limited to the activities covered by Art. $5 \S 4$ which are not PE. In practice even if the conditions of the three-pronged test are met, Art. $5 \S 5$ does not apply if the activities performed by the person on behalf of the enterprise are limited to activities mentioned in Art. 5 \$ 4. Likewise, as before Model 2017, even if the conditions of the three-pronged test are met, Art. $5 \S 5$ does not apply if the activities are covered by the independent agent exception of Art. $5 \S 6$.

Art. $5 \S 5$ does not apply to situations where a person concludes contracts on its own behalf and obtains goods or services from other enterprises or arranges for other enterprises to deliver such goods or services to comply with the obligations deriving from these contracts. For example a distributor of products who sells to customers in the SC products that it buys from an enterprise, it is neither acting on behalf of that enterprise nor selling property that is owned by that enterprise since the property that is sold to the customers in the $\mathrm{SC}$ is owned by such distributor. In these cases, the person is not acting 'on behalf of other enterprises and the contracts concluded by the person are neither in the name of these enterprises nor for the transfer to third parties of the ownership or use of property that these enterprises own.

The Commentary now clarifies that there is a 'conclusion of contracts' in all situations where, under the relevant law governing contracts, a contract is considered to have been concluded by a person. A contract may be concluded without any active negotiation of the terms of that contract when, for example, the relevant law provides that a contract is concluded by reason of a person accepting, on behalf of an enterprise, the offer made by a third party to enter into a standard contract with that enterprise. Also, a contract may, under the relevant law, be concluded in a state even if that contract is signed outside that state; this occurs for example when the conclusion of a contract results from 
the acceptance, by a person acting on behalf of an enterprise, of an offer to enter into a contract made by a third party. ${ }^{87}$

1.57 Art. 5 § 5 of Model 2017 not only looks at the authority to conclude contracts or to the habitual conclusion of contracts as before, but also extends to a situation in which a person "habitually plays the principal role leading to the conclusion of contracts that are routinely concluded without material modification by the enterprise'. The Commentary clarifies that these situations occur when the conclusion of a contract directly results from the actions that the person performs in a CS on behalf of the enterprise even though, under the relevant law, the contract is not concluded by that person in that state. In practice there is an agency-PE when activities that a person exercises in a state result in the regular conclusion of contracts to be performed by a foreign enterprise, i.e., where that person acts as the sales force of the enterprise. ${ }^{88}$

1.58 The Commentary further clarifies that the reference to 'contracts that are routinely concluded without material modification by the enterprise' implies that the person who 'habitually plays the principal role leading to the conclusion of contracts' in the $\mathrm{SC}$ is an agency-PE even if the contracts are not formally concluded in that state, for example, where the contracts are routinely subject, outside that state, to review and approval without such review resulting in a modification of the key aspects of these contracts. So there is an agency-PE when, for example, a person solicits and receives (but does not formally finalize) orders which are sent directly to a warehouse from which goods belonging to the enterprise are delivered and where the enterprise routinely approves these transactions. By contrast, there is no agency-PE when a person merely promotes and markets goods or services of an enterprise in a way that does not directly result in the conclusion of contracts, for example when representatives of a pharmaceutical enterprise promote drugs produced by that enterprise by contacting doctors who subsequently prescribe these drugs. ${ }^{89}$

1.59 Contractual arrangements setting up commissionaire structures have in the past traditionally posed the issue of whether the commission agent was an agency-PE. In a commissionaire arrangement, a commission agent in the SC acts on behalf of a foreign enterprise but, in doing so, concludes in its own name contracts with third parties that do not create rights and obligations that are legally enforceable between the foreign enterprise and the third parties 
even though the foreign enterprise directly transfers to these third parties the ownership or use of property that it owns or has the right to use that property.

Before the changes to Model 2017 it was excluded that a commission agent was an agency-PE if his activities were limited to those mentioned at the end of Art. $5 \S 5$, even if the agent sold the goods or merchandise of the enterprise in his own name, and this was confirmed by leading cases. ${ }^{90}$ Even if the Model 2017 does not refer explicitly to commissionaire structures, the Commentary now explicitly affirms that these structures are covered by Art. $5 \S 5$, when contracts are concluded with clients by an agent, a partner or an employee of an enterprise so as to create legally enforceable rights and obligations between the enterprise and these clients. ${ }^{91}$

Under Art. $5 \S 5$ there is an agency-PE where a person is acting in a CS on 1.61 behalf of an enterprise and has, and habitually exercises, in a CS, an authority to conclude contracts, and these contracts - even if they are not in the name of the foreign enterprise - are for (i) the transfer of the ownership of property owned by that enterprise or (ii) the provision of services by that enterprise. These situations occur when the contracts that relate to the transfer of the ownership of property, or the provision of services, are performed by the foreign enterprise, and not by the person who acts on the enterprise's behalf. It is worth noting that under Art. $5 \S 5$ there is an agency-PE in the above situations also when there is (i) the granting of the right to use property owned by that enterprise or (ii) the granting of the right to use property that the enterprise has the right to use or (iii) the transfer of the ownership of property that the enterprise has the right to use. ${ }^{92}$

The work on Action 7 led to changes to the wording of Art. $5 \S 6$ to address the artificial avoidance of PE status. Art. $5 \S 6$ defines the concept of 'independent agent' which is not an agency-PE. Art. $5 \S 6$ was replaced in Model 2017 and Art. 13 MLI contains a similar rule.

Before the change Art. $5 \S 6$ provided that an enterprise was not to be deemed to have a $\mathrm{PE}$ in a CS merely because it carried on business in that state through a broker, general commission agent or any other agent of an independent status, provided that such persons were acting in the ordinary course of their business.

90 France, Conseil d'État 304715, 308525; Norway, Høyesterett HR-2011-02245-A (sak nr. 2011/755), 2 December 2011.

91 Commentary to Art. 5 \$ 92 .

92 Commentary to Art. $5 \S 94$. 
Under that provision the independence of the agent was determined essentially by a two-prong test: (i) the agent had to be independent of the enterprise both legally and economically (this analysis also relied on the lack of detailed instructions by the principal, and the fact that entrepreneurial risk is borne by the agent); and (ii) the agent had to act in the ordinary course of his business when acting on behalf of the enterprise..$^{93}$ Furthemore the analysis of whether an agent acted in the ordinary course of his business was developed using two basic indicators: (i) whether the activities belonged to agent's own economic sphere or to the sphere of the principal; and (ii) whether the agent had one or more principals. The Commentary suggested that the business activities carried out within agent's trade should be compared to the other business activities carried out by that agent. ${ }^{94}$

1.64 Art. $5 \S 6$ in the current version now provides that Art. $5 \S 5$ shall not apply where the person acting in a CS on behalf of an enterprise of the other CS carries on business in the first-mentioned state as an independent agent and acts for the enterprise in the ordinary course of that business. The previous reference to 'a broker, general commission agent or any other agent of an independent status' has been deleted because it created confusion when applied to different civil law or common law systems and now one has to refer to the requirement of the 'ordinary course of business'.

1.65 The Commentary explains that now the central criterion to exclude that a person is an agency-PE under Art. $5 \S 6$ is that it acts in the 'ordinary course of business'. An agent is independent - and not an agency-PE - when it acts in the ordinary course of its business as agent, i.e., when it performs activities that are related to that agency business. So an agent does not act in the ordinary course of its business as agent when it performs activities that are unrelated to that agency business. Let us take for example company $\mathrm{X}$ that (i) acts on its own account as a distributor for companies a, b, c, and (ii) also acts as an agent for company $\mathrm{d}$. In this situation the activities that company $\mathrm{X}$ undertakes as a distributor for companies $\mathrm{a}, \mathrm{b}, \mathrm{c}$, are not part of the activities that company $\mathrm{X}$ carries on in the ordinary course of its business as an agent for company d. ${ }^{95}$

93 Commentary 2014 to Art. 5 \$37, which has been deleted in Commentary 2017. See: Belgium, Cour d'Appel Bruxelles, 1992-02-18, 18 February 1992.

94 Commentary 2014 to Art. 5 § 38.8, which has been deleted in Commentary 2017. See: India, High Court of Delhi, Rolls Royce Singapore Pvt. Ltd. v. ADIT, 30 August 2011; Germany, Bundesfinanzhof (Federal Fiscal Court), I R 116/93, 14 September 1994; Denmark, Højesteret, 7/1991, 25 June 1996.

95 Commentary to Art. 5 § 110. 
The Commentary clarifies that Art. $5 \S 6$ only applies to persons who act on behalf of an enterprise in the course of carrying on a business as an independent agent, but does not apply to persons who act on behalf of an enterprise in a different capacity, such as where an employee acts on behalf of her employer or a partner acts on behalf of a partnership. ${ }^{96}$

The Commentary provides a series of indicators that can be used, either in isolation or in combination, to determine whether an agent is independent. These indicators are: subsidiary's independence, control/detailed instructions, number of principals, limitations on scale of business, and provision of information. With regard to limitations on scale of business, the Commentary observes that the extent to which the agent exercises freedom in the conduct of business on behalf of the principal within the scope of the authority conferred by the agreement is not relevant. With regard to the provision of information, the Commentary notes that the fact that the agent provides substantial information to the principal is not in itself a sufficient criterion, while the fact that the agent provides substantial information to the principal to seek approval is an indication of dependence. ${ }^{97}$

Additional requirements of independence are that: (i) the agent's commercial 1.68 activities for the enterprise are not subject to detailed instructions or to comprehensive control; and (ii) the entrepreneurial risk is borne by the agent. ${ }^{8}$ An independent agent is responsible to his principal for the results, but is not subject to significant control on how work is carried out, or to detailed instructions. ${ }^{99}$

Art. $5 \S 6$ in the current version however provides that a person who acts exclusively or almost exclusively on behalf of one or more enterprises to which it is closely related shall not be considered to be an independent agent with respect to any such enterprise. So the number of principals is an important indicator of the independence of the agent: while only one principal is an indicator of the fact that the agent is essentially captive of that principal, the existence of several principals is an indicator of the fact that the agent is

96 Commentary to Art. 5 § 103.

97 Commentary to Art. 5 108. See: Canada, Tax Court of Canada, American Life Insurance Co. v. Her Majesty the Queen, 16 May 2008, United States, US Tax Court, Taisei Fire and Marine Insurance Co. Ltd. et al. v. Commissioner of Internal Revenue, 2 May 1995; The Netherlands, Gerechtshof Den Haag, BK 07/00604, 15 July 2008; Denmark, Højesteret (Supreme Court), 1. afdeling, 142/2001, 5 February 2004; India, Income Tax Appellate Tribunal (ITAT), Delmas France Mumbai v. ADIT, 11 January 2012.

98 Commentary to Art. 5 § 104.

99 Commentary to Art. 5 § 106. See: United States, US Tax Court, Taisei Fire and Marine Insurance Co. Ltd. et al. v. Commissioner of Internal Revenue, 2 May 1995; India, High Court of Delhi, Rolls Royce Singapore Pvt. Ltd. v. ADIT, 30 August 2011; Canada, Tax Court of Canada, American Life Insurance Co. v. Her Majesty the Queen, 16 May 2008. 
operating as an autonomous entity (i.e., in the ordinary course of business). An agent acts for a number of principals in the ordinary course of its business when none of the principals is predominant in terms of the business carried on by the agent. ${ }^{100}$

1.70 Independent status is less likely if the activities of the person are performed wholly or almost wholly on behalf of only one enterprise, or a group of enterprises that are 'closely related' to each other, over the lifetime of that person's business or over a long period of time. Where, however, a person is acting exclusively for one enterprise to which it is not 'closely related', even if that occurs only for a short period of time (e.g. at the beginning of that person's business operations), it is possible that Art. $5 \S 6$ applies. ${ }^{101}$

1.71 Art. $5 \S 8$ explains the meaning of the concept of a person or enterprise 'closely related' to an enterprise for the purposes of Art. $\S 6$. A person or enterprise is closely related to an enterprise if, based on all the relevant facts and circumstances, one has control of the other or both are under the control of the same persons or enterprises. In any case, a person or enterprise shall be considered to be closely related to an enterprise if one possesses directly or indirectly more than 50 per cent of the beneficial interest in the other (or, in the case of a company, more than 50 per cent of the aggregate vote and value of the company's shares or of the beneficial equity interest in the company) or if another person or enterprise possesses directly or indirectly more than 50 per cent of the beneficial interest (or, in the case of a company, more than 50 per cent of the aggregate vote and value of the company's shares or of the beneficial equity interest in the company) in the person and the enterprise or in the two enterprises.

\section{F. Structures in shipping and air transport}

1.72 The operation of ships/aircraft/boats in international traffic is traditionally kept out of the Art. 5 approach to the PE because of the peculiar structure of firms operating in this field. Before the changes of Model 2017 Art. 8 in fact provided that profits from the operation of ships/aircraft/boats in international traffic were taxable only in the CS in which the effective place of management of the enterprise was situated, thereby excluding the need to assess whether

100 However, the fact that different principals act in concert to control the acts of the agent is an indication of dependence: Commentary to Art. 5 § 110 .

101 Commentary to Art. $5 \S 111$. India, High Court of Delhi, Rolls Royce Singapore Pvt. Ltd. v. ADIT, 30 August 2011. 
the operation in the $\mathrm{SC}$ was indeed a PE. ${ }^{102}$ As the country of the effective place of management of the enterprise usually coincides with the RC, Art. 8 $\S 1$ appeared to adopt a principle of exclusive taxation in the RC.

The Commentary, however, already mentioned different models of taxation of this kind of income, such as exclusive taxation in the $\mathrm{RC}$, and a combination of exclusive taxation in the CS where effective place of management and in the RC. Art. 8 has now been entirely remodelled by Model 2017. It previously contained four paragraphs and generally adopted the criterion of the effective place of management of the enterprise. Paragraphs $2-4$ have been eliminated and Art. $8 \S 1$ now provides that the profits of an enterprise of a CS from the operation of ships or aircrafts in international traffic shall be taxable only in that state. A review of the treaty practices of OECD and non-OECD countries revealed that the majority of these states preferred to assign the taxing right to the state of the enterprise, rather than to the CS in which the place of effective management of the enterprise was situated. In this respect it should be noted that pursuant to Art. $3 \S 1 \mathrm{~d}$ ) of the Model the term 'enterprise of a CS' means an enterprise carried on by a resident of the CS.

Moreover Model 2017 eliminated within Art. 8 the reference to inland waterways transport' so that now the reference is exclusively to profits from international shipping and air transport, and all kinds of these activities are regulated by Art. $8 \S 1$.

It should also be noted that Model 2017 modified the concept of 'international traffic'. Before 2017 subparagraph e) of Art. 3 defined the term 'international traffic' as any transport by a ship or aircraft, except when the ship or aircraft was operated solely between places in the other. Now the subparagraph provides that the term 'international traffic' means any transport by a ship or aircraft, except when the ship or aircraft is operated solely between places in a $\mathrm{CS}$ and the enterprise that operates the ship or aircraft is not an enterprise of that state. As noted by the Commentary the definition was amended in 2017 to ensure that it also applied to a transport by a ship or aircraft operated by an

102 See in general: Beckermann, Florian, 'Conflicts of Qualification and Income Derived from International Shipping, Inland Waterways Transport and Aircraft Business (Art. 8 OECD MC)' in: Lang, Michael, et al., (eds), Tax Treaties: Building Bridges between Law and Economics (IBFD 2010); Cutrera, Margherita, 'Art. 8 Shipping, Inland and Waterways Transport and Air Transport' in: Ecker, Thomas and Ressler, Gernot (eds), History of Tax Treaties: The Relevance of the OECD Documents for the Interpretaion of tax Treaties (Linde 2011); Glicklich, Peter A. and Miller, Michael, U.S. Taxation of International Shipping and Air Transport Activities (Bloomberg Bna 2005); Maisto, Guglielmo, 'Shipping, Inland Waterways Transport and Air Transport (Art. 8 OECD Model Convention)' in: Lang, Michael (ed.), Source Versus Residence: Problems Arising from the Allocation of Taxing Rights in Tax Treaty Law and Possible Alternatives (Kluwer Law International 2008). 
enterprise of a third state. The reason for that is the different language which now explicitly allows the application of $\S 3$ of Art. 15 to a resident of a CS who derives remuneration from employment exercised aboard a ship or aircraft operated by an enterprise of a third state. In spite of the change of definition Art. 8 as a whole continues to apply only to the profits of an enterprise of a CS. 103

1.76 Art. 8 continues to be the same: to ensure that profits from the operation of ships/aircrafts in international traffic are taxed in one state alone and not in the SC. ${ }^{104}$ It should be noted that even if Art. $8 \S 1$ directly attributes taxing power only to one CS, national courts tend to erode this principle (when included in actual treaties) using different strategies. One of them is to circumscribe the application of Art. $8 \S 1$ only to international operations, or distinguishing activities not included in the exclusive $\mathrm{RC}$ taxation principle. ${ }^{105}$

1.77 Exclusive taxation in the country of the enterprise (Art. $8 \S 1$ ) applies to core activities and extended activities (which include directly connected activities, and ancillary activities). The profits covered by Art. $8 \S 1$ are generally the profits directly obtained by the enterprise from core activities, i.e. the transportation of passengers or cargo by ships or aircraft (whether owned, leased or otherwise at the disposal of the enterprise) that it operates in international traffic. ${ }^{106}$ Extended activities are those that permit, facilitate or support their international traffic operations and the profits derived therefrom are covered by Art. $8 \S 1$, namely they cannot be taxed in the SC. ${ }^{107}$

1.78 Art. $8 \S 1$ also covers activities which are directly connected with the core and extended activities. Any activity carried on primarily in connection with the transportation, by the enterprise, of passengers or cargo by ships or aircrafts that it operates in international traffic should be considered to be directly connected with that transportation. Art. $8 \S 1$ also covers activities which are not directly connected with the operation of the enterprise's ships or aircrafts in international traffic as long as they are ancillary to such operations. ${ }^{108}$

103 Commentary to Art. $3 \S 6.1$.

104 Commentary to Art. 8 1. See: Zimbabwe, Federation of Rhodesia and Nyasaland - Special Court, Undisclosed v. The Commissioner, 24 May 1964, 26 SATC 226(F).

105 Germany, Finanzgericht Berlin-Brandenburg, 8 K 8084/97, 17 January 2000; Canada, Supreme Court of Canada, Furness, Withy \& Co. v. Her Majesty the Queen, 29 January 1968; Germany, Bundesfinanzhof, I B 40/94, 14 September 1994; France, Conseil d'État, 249801, 15 July 2004; Italy, Corte Suprema di Cassazione 7609, 1 September 1994.

106 Commentary to Art. 8 § 4 .

107 Commentary to Art. 8 § 4 .

108 Commentary to Art. 8 § 4.1. See: South Africa, Transvaal Tax Court, Company name not disclosed v. Commissioner for Inland Revenue, 25 May 1990. 
The Commentary focuses on various types of activities which, depending on the circumstances, fall or do not fall under the scope of core or extended activities covered by Art. $8 \S 1$. These activities include leasing of fully equipped ships/aircraft, slot-chartering, international and domestic combinations, sale of tickets, advertising, use of containers, ground operations, pooling arrangements, shipbuilding, and investment income related to shipping activities. ${ }^{109}$ Fishing, dredging or hauling activities on the high seas should fall under Art. 8,110 but this obviously depends on specific circumstances. ${ }^{111}$ Leasing of fully equipped ships/aircraft falls under Art. $8 \S 1$, but national courts often adopt a restrictive view in this matter. ${ }^{112}$

Investment income related to shipping activities (e.g., income from stocks, bonds, shares or loans) falls under Art. $8 \S 1$ if the investment is an integral part of the carrying on of the business of operating the ships or aircraft in international traffic ${ }^{113}$ (for example of interest generated by the cash required in a CS for the carrying on of that business or by bonds posted as security where this is required by law in order to carry on the business). By contrast, Art. $8 \S 1$ does not apply, for example, to interest from cash-flow or other treasury activities for PEs of the enterprise, or to interest from short-term investment of the profits generated by the local operation of the business if the funds invested are not required for that operation. ${ }^{114}$ Other examples of profits not covered by Art. $8 \S 1$ include profits arising from currency gains and damages awarded after the cancellation of a contract to build a ship in so far as they do not constitute profits from the operation of a ship in international traffic (the ship was not currently operating), ${ }^{115}$ or income from a paragliding school in so far as it did not constitute an air transport business within the meaning of the relevant international transport article. ${ }^{116}$

The reference in Art. 8 to operation of boats engaged in inland waterways transport has been eliminated, but previously Model 2017 Art. 8 \$ 2 provided that profits from the operation of those boats were taxable only in the CS in which the effective place of management of the enterprise was situated. Art. 8 $\S 2$ applied not only to inland waterways transport between two or more

109 Commentary to Art. 8 $\S 6-12,14$ and 17.

110 Commentary to Art. $8 \S 18$.

111 The Netherlands, Hoge Raad der Nederlanden, 35.769, 20 December 2000.

112 Canada, Federal Court of Appeal, Gulf Offshore N.S. Ltd. v. Her Majesty the Queen, 21 September 2007; France, Cour Administrative d'Appel Nancy, 89NC00529-89NC00531, 10 October 1991.

113 Commentary to Art. $8 \S 14.1$.

114 Commentary to Art. 8 14.2. See: United States, US Court of Federal Claims, Qantas Airways Ltd. v. United States (Internal Revenue Service), 4 April 1997.

115 Germany, Bundesfinanzhof I R 31/02, 1 April 2003.

116 Austria, Verwaltungsgerichtshof, 2005/15/0072, 19 March 2008. 
countries, but also to inland waterways transport carried on by an enterprise of one country between two points in another country. ${ }^{117}$ Art. $8 \S 2$ has now been eliminated by Model 2017. The goal of Art. 8 \$2 was to apply to inland waterways transport the same treatment as to shipping and air transport in international traffic, so that the rules with respect to the taxing right of the effective place of management country as set forth in Art. $8 \S 1$ applied also to activities covered by Art. $8 \S 2 ;{ }^{118}$ paragraphs $4-14$ of the Commentary to Art. 8 (dealing specifically with Art. 8 § 1 ) thus continue to apply, with the necessary adaptations, for purposes of determining which profits may be considered to be derived from the operation of boats with respect to inland waterways transport. ${ }^{119}$

1.82 Enterprises exclusively engaged in shipping, inland waterways transport or air transport before Model 2017 came under Art. 8 § , as regards profits arising to them from the operation of ships or aircraft belonging to them. ${ }^{120}$ The Commentary makes a distinction between foreign PEs exclusively engaged and foreign PEs not exclusively engaged in shipping or air transport. The former situation occurs when an enterprise has in a foreign country PEs exclusively concerned with the operation of its ships or aircrafts, and so the SC does not have a power to tax the profits of the PE. ${ }^{121}$ By contrast, a foreign PE exclusively engaged in inland waterways transport was deemed to be a PE that received goods carried by third parties on its own ships: also in this case the SC does not have the power to tax the profits of the PE. ${ }^{122}$

1.83 Before Model 2017, Art. $8 \S 3$ provided that if the effective place of management of a shipping enterprise or of an inland waterways transport enterprise was aboard a ship/boat, then it was deemed to be situated in the CS in which the home harbour of the ship/boat is situated, or, if there was no such home harbour, in the CS of which the operator of the ship/boat is a resident. ${ }^{123}$ Art. $8 \S 3$ has now been eliminated by Model 2017.

1.84 Art. $8 \S 4$ has been maintained in Model 2017 and renamed Art. 8 §2. It provides that Art. $8 \S 1$ shall also apply to profits from the participation in a pool, a joint business or an international operating agency. This includes

117 Commentary to Art. 8 § 16; Germany, Finanzgericht Nordrhein-Westfalen, 2 K 92/99, 22 June 2001.

118 Commentary to Art. $8 \S \S 15-16$.

119 Commentary to Art. 8 § 16.1 .

120 Commentary to Art. 8 § 18-19.

121 Commentary to Art. $8 \S 20$.

122 Commentary to Art. 8 § 21-22.

123 The Netherlands, Hoge Raad der Nederlanden, No. AWB 10/00157, 25 March 2011. 
various forms of international company operation that exist in shipping or air transport, such as pooling agreements or other treaties. ${ }^{124}$

\section{FORCE OF ATTRACTION OF THE PE}

Art. $7 \S 4$ provides that if profits include items of income that are dealt with separately in other articles of the Convention, then the provisions of those articles shall not be affected by the provisions of Art. 7. This means that the provisions of those articles operate instead of Art. 7 in so far as the situations of 'isolated income' covered by those articles are not attracted to taxation as business profits of the PE under the concept of the 'limited force of attraction of the PE'. In other words: in these cases the existence of the PE does not, per se, determine that the foreign person is taxable in the SC. This section on separate taxation of business profits under Art. $7 \S 4$ is preceded by general remarks on the 'effectively connected' concept and then focuses on the relationship between Art. 7 with other articles from the perspective of the treaty in the SC.

If the profits of an enterprise include categories of income which are dealt with separately in other articles of the Convention, i.e., dividends, the question that arises is which article should apply to these categories of income, for example in the case of dividends, should Art. 7 or Art. 10 apply (and so on for other treaty articles)? ${ }^{25}$ The Commentary summarizes longstanding differences of view. According to the so-called 'full force of attraction', income such as other business profits, dividends, interest and royalties arising from sources in the $\mathrm{SC}$ are fully taxable by the SC if the beneficiary has a PE therein, even though such income is not attributable to that PE. According to the so-called 'limited (or restricted) force of attraction' in taxing the profits that a foreign enterprise derives from the SC, tax authorities of the SC should look at separate sources of profit, subject to the possible application of other articles of the Convention. ${ }^{126}$

The Commentary is based on the restricted force of attraction and notes that this solution allows simpler and more efficient tax administration and compliance, and is more closely adapted to the way in which business is commonly carried on. The organization of modern business is highly complex. ${ }^{127}$ So the 
restricted force of attraction is a rule of interpretation that ensures that articles applicable to specific categories of income have priority over Art. 7,128 clarifying that Art. $7 \S 4$ does not govern the manner in which income will be classified for the purposes of domestic laws. ${ }^{129}$

1.88 The restricted force of attraction, to operate, needs a criterion to distinguish which kinds of income are 'attracted' by the $\mathrm{PE}$, and which other kinds of income are not 'attracted' and are therefore 'isolated'. This criterion is the 'effectively connected' concept. The Commentary affirms that Art. 7 applies only to business profits which do not belong to categories of income covered by these other articles, but does not apply to other specific categories of income. ${ }^{130}$

\section{A. Which activities are 'attracted' by the PE?}

1.89 There are specific treaty articles that operatively establish when income (otherwise 'isolated') becomes effectively connected (Artt. $10 \S 4,11 \S 3,12$ $\S 2$, and $21 \S 2$, hereinafter the ' $E F C$ rules'). The Commentary addresses these different situations of effectively connected income, but has a common structure in respect of dividends (Art. $10 \S 4$ ), interest (Art. $11 \S 4$ ), royalties (Art. $12 \S 3$ ), and other income (Art. $21 \S 2$ ).

1.90 In the first place the Commentary provides that dividends, interest, royalties, and other income arising in the SC and payable to taxpayers resident in the $\mathrm{RC}$ fall outside the scope of arrangements made to prevent those types of income from being taxed both in the $\mathrm{SC}$ and in the $\mathrm{RC}$ (i.e., the $\mathrm{CS}$ of the beneficiary's residence) if the beneficiary of those types of income has a $\mathrm{PE}$ in the SC.

1.91 The Commentary generally observes that EFC rules are not based on the 'full force of attraction of PE', and suggests that those articles do not stipulate that dividends, interest, royalties and other income flowing to a resident of the $\mathrm{RC}$ from a source situated in the $\mathrm{SC}$ must be related to a $\mathrm{PE}$ which that resident may have in the SC. By contrast, the Commentary explains that those articles provide that in the $\mathrm{SC}$ those dividends, interest, royalties and other income are taxable as part of the profits of a $\mathrm{PE}$ there owned by the beneficiary resident in the $\mathrm{RC}$, only if they meet a specific connection requirement. In the cases indicated 
above each of the EFC rules relieves the SC from any limitations under Arts. $10,11,12$ and 21.

The Commentary observes that the EFC rules rely on an 'economic ownership' concept. The Commentary also suggests that the 'economic' ownership of participations (dividends), debt claims (interest), right or property (royalties), or assets (other income) is determined under the principles developed in the CFA's report Attribution of Profits to PEs ( $§ 72-97)$. Moreover, according to the Commentary, the requirement that participations (dividends), debt claims (interest), right or property (royalties) or assets (other income) be 'effectively connected' to the PE requires more than merely recording items in the books of the PE for accounting purposes.

The transfer of participations (dividends), debt claims (interest), right or property (royalties) or assets (other income) to PEs set up solely for that purpose in countries that offer a preferential tax regime to those classes of income triggers the application of domestic anti-abuse rules.

This part of the chapter focuses more specifically on the relationship of Art. 7 with EFC rules.

\section{Effectively connected dividends}

Art. $10 \S 4$ provides that Art. $10 \S \S 1$ and 2 shall not apply if the beneficial owner of the dividends, being a resident of the $\mathrm{RC}$, carries on business in the $\mathrm{SC}$ (the CS of which the company paying the dividends is a resident) through a $\mathrm{PE}$ situated in the $\mathrm{SC}$ and the participation in respect of which the dividends are paid is effectively connected with such a PE. In such a case, Art. 7 shall apply. ${ }^{131}$

\section{Effectively connected interest}

Art. $11 \S 5$ provides that if the person paying the interest (whether he is a resident of the $\mathrm{SC}$, the $\mathrm{RC}$ or a third country), has in a CS a PE in connection with which the indebtedness on which the paid interest was incurred, and such interest is borne by such $\mathrm{PE}$, then such interest shall be deemed to arise in the $\mathrm{SC}$ (the state in which the PE is situated). The application of this rule has led to distinguish, from the perspective of the $\mathrm{SC}$, situations in which interest is not attracted ('isolated interest'), by the $\mathrm{PE}$ and situations in which interest is attracted by the PE. ${ }^{132}$ The general principle established by Art. $11 \S 1$ is that 
the SC of the interest is the state of which the payer of interest is a resident. An exception is made by Art. $11 \S 5$ in the case of interest-bearing loans that have an obvious economic link with a PE owned in the SC by the payer of the interest. Art. $11 \S 5$ provides that: if (i) the loan was contracted for the requirements of that $\mathrm{PE}$ in the $\mathrm{SC}$; and (ii) the interest is borne by that $\mathrm{PE}$, then the source of the interest is in the CS in which the PE is situated (the $\mathrm{SC}$ ), leaving aside the place of residence of the owner of the PE (a third country or the RC). ${ }^{133}$

1.97 National courts have applied the 'restricted force of attraction of PE' to determine, on the basis of the OECD guidelines described above, in which cases interest is not attracted and therefore subject to isolated treaty treatment and developed various criteria. ${ }^{134}$ The link, for example occurs if the management of the PE has contracted a loan, which it uses for the specific requirements of the $\mathrm{PE}$, and shows it among its liabilities and pays the interest thereon directly to the creditor. A second situation is one in which the head office of the enterprise has contracted a loan the proceeds of which are used solely for the purposes of a $\mathrm{PE}$ situated in another country (the interest is serviced by the head office but is ultimately borne by the PE). By contrast, if the loan is contracted by the head office of the enterprise and its proceeds are used for several PEs situated in different countries the requirements of the second sentence of Art. $11 \S 5$ are not met, and the state where the PE is situated is not the $\mathrm{SC}$ for the purposes of the treaty (i.e., the state where the interest is deemed to arise). This situation falls outside Art. $11 \S 5.135$

1.98 Art. $11 \S 5$ regulates the tax treatment of interest borne by a PE situated either in the $\mathrm{SC}$ or in a third country and received by a taxpayer resident in the $\mathrm{RC}$, but also indirectly provides a ban on extraterritorial taxation in the $\mathrm{SC}$ on interest paid to a recipient in the $\mathrm{RC}$ but effectively attributable to a $\mathrm{PE}$ in the SC. ${ }^{136}$ In the situation just described the state where the $\mathrm{PE}$ is situated is not entitled to tax such interest if there is no economic link between the loan on which the interest arises and the PE. In other words, the exception to the general rule made by Art. $11 \S 5$ operates only where the economic link between the loan and the PE is sufficiently clear-cut. This link occurs in

133 Commentary to Art. 11 § 26.

134 Germany, Finanzgericht Bayern 9 K 3576/01, 10 December 2003, 4; Belgium, Hof van Beroep Gent, 1995/FR/59, 1 April 2003; Germany, Bundesfinanzhof, I R 5/06, 17 October 2007.

135 Belgium, Hof van Beroep Gent, 2000/83, 27 April 2000, 7; Spain, Tribunal Económico Administrativo Central, 2007-03-15, 15 March 2007.

136 Germany, Bundesfinanzhof, I R 128/80, 9 October 1985; Germany, Bundesfinanzhof, I R 54/92, 20 January 1993. 
several situations in which the requirements of the second sentence of Art. 11 $\S 5$ are met.

\section{Effectively connected royalties}

Art. $12 \S 3$ provides that Art. $12 \S 1$ shall not apply if the beneficial owner of the royalties, being a resident of the $\mathrm{RC}$, carries on business in the $\mathrm{SC}$ in which the royalties arise through a $\mathrm{PE}$ situated therein and the right or property in respect of which the royalties are paid is effectively connected with such PE; in such a case Art. 7 shall apply. ${ }^{137}$ In respect of outbound royalties courts of the SCs have generally checked whether a $\mathrm{PE}$ of the foreign recipient actually existed in the SC to establish a tax charge leading to the application to the business profit treaty article. ${ }^{138}$

\section{Effectively connected capital gains}

The allocation rule of Art. $13 \S 2$ is that gains from the alienation of movable property forming part of the business property of a $\mathrm{PE}$ which an enterprise of the $\mathrm{RC}$ has in the $\mathrm{SC}$, including such gains from the alienation of such a $\mathrm{PE}$ (alone or with the whole enterprise), may be taxed in that SC. 'Movable property' is defined as all property other than immovable property, which is dealt with in Art $13 \S 1$, including intangible property, such as goodwill, licences, etc. Art. $13 \S 2$ applies in two instances: (i) when movable property of a PE is alienated; or (ii) when a PE as such (alone or with the whole enterprise) is alienated. If the whole enterprise is alienated, then Art. $13 \S 2$ applies to gains deemed to result from the alienation of movable property forming part of the business property of the PE, with the result that Art. 7 applies. ${ }^{139}$

\section{Effectively connected other income}

The rule adopted by Art. $21 \S 2$ is the force of attraction on other income effectively connected to a $\mathrm{PE}$, i.e., the so-called 'restricted force of attraction of the PE'. Under this rule the other income arising in the $\mathrm{SC}$ and payable to taxpayers resident in the RC falls outside the scope of Art. $21 \S 1$ (no tax in the $\mathrm{SC}$ ) if the recipient of that other income has a $\mathrm{PE}$ in the $\mathrm{SC}$, and the other income is effectively connected to that PE, so in practice Art. $21 \S 2$ relieves the SC from any limitations to its treaty taxing power imposed by Art. $21 \S 1$.

137 Commentary to Art. 12 § 20-21.2.

138 Germany, Bundesfinanzhof, I R 84/99-I R 112/94, 29 November 2000.

139 Commentary to Art. 13 § 24-25. See: United States, US Tax Court, Jan Casimir Lewenhaupt v. Commissioner of Internal Revenue, 23 April 1953; Germany, Bundesfinanzhof, I B 191/09, 19 May 2010. 
1.102 If other income is 'associated' with the activity of a PE (of a taxpayer resident of the $\mathrm{RC}$ ) situated in the treaty $\mathrm{SC}$, then Art. 7 applies, triggering taxation in the treaty SC of PE's income, including other income. ${ }^{140}$ This is an exception authorized by Art. $21 \S 2$, to Art. $21 \S 1$, so the treaty SC may tax. ${ }^{141}$ National Courts have generally construed this situation as an authorized derogation by the business profits article to the other income article (based under Art. $21 \S 1$ of the Model), typically in cases involving participations of active partners in small companies. ${ }^{142}$

1.103 Art. $21 \S 2$ (instead of Artt. 10,11, or 12) specifically regulates the treatment of dividends, interest or royalties arising in the $\mathrm{SC}$ which are 'attributable' to a $\mathrm{PE}$ which a taxpayer resident of the $\mathrm{RC}$ has in the $\mathrm{SC}$. This concept of dividends, interest or royalties arising in the $\mathrm{SC}$ which are 'attributable' to a $\mathrm{PE}$ in practice overlaps with the effectively connected concept used by Artt. 10 $\S 5,11 \S 4$, and $12 \S 3$.

1.104 The situations concerning dividends, interest and royalties are often the result of abuses in which the foreign PE is set up solely to benefit from low taxes in countries that offer preferential treatment to income. These abuses are carried out: (i) for dividends through the transfer of shares to PEs set up solely for that purpose in countries that offer preferential treatment to dividend income; (ii) for interest through the transfer of loans to PEs; and (iii) for royalties through the transfer of intangibles to PEs. The Commentary 2017 fills a gap and directly addresses these abusive structures, stating that they can be addressed by Art. $29 \S 8$ and that to secure treaty benefits the requirement that a shareholding be 'effectively connected' to such a location requires more than merely recording the shareholding in the books of the PE for accounting purposes. ${ }^{143}$

\section{B. Separate treatment of isolated classes of income}

1.105 In many situations courts have not relied on the effectively connected income concept, but have focused directly on whether separate treatment applied, that is whether specific treaty articles on isolated classes of income applied instead of the business profits treaty article. More specifically case law addressed the application of the business profits article vis-à-vis income from immovable

140 The term 'other income associated to a PE', in practice has the same meaning as the terms 'income effectively connected to a PE', or 'income attributable to a PE' used by the Commentary to Art. 21 .

141 Commentary to Art. $21 \S 4-1$.

142 Belgium, Hof van Cassatie/Cour de Cassation, F1851N, 21 December 1990; The Netherlands, Hoge Raad der Nederlanden, 42.292, 12 October 2007.

143 Commentary to Art. $10 \S 32 ; 11 \S 12$, and $12 \S 5$. 
property of an enterprise (Art. $6 \S 4$ ), income from personal services (Artt. 15, 16, 17 and 18), and royalties (Art. 12).

Art. $6 \S 4$ provides that Art. $6 \S \S 1$ and 3 shall also apply to the income

from immovable property of an enterprise. The Commentary clarifies that the right to tax the $\mathrm{SC}$ has priority over the right to tax of the $\mathrm{RC}$ and applies also where the income of an enterprise is only 'indirectly derived' from immovable property. ${ }^{144}$ One therefore can distinguish between: (i) income from immovable property which is part of a $\mathrm{PE}$ in the $\mathrm{SC}$; and (ii) income from immovable property which is not part of a $\mathrm{PE}$ in the SC. When income from immovable property is not actually part of the income of a $\mathrm{PE}$ in the $\mathrm{SC}$ the immovable property article of the relevant treaty is applied instead of the business profit article. ${ }^{145}$ Courts had to decide whether income from immovable property was actually part of the income of a $\mathrm{PE}$ in the SC and whether the immovable property article or the business profits article of the relevant treaty applied. ${ }^{146}$

Case law also addressed the application of Art. 7 vis-à-vis income from personal services (Artt. 15, 16, 17 and 18). When a non-resident is employed in individual work in the $\mathrm{SC}$ usually the employment article applies, providing tests under which the employment income of such an individual is taxable exclusively in her/his RC. Art. 7, however, can apply when activities are carried out pursuant to a contract for services (as opposed to a contract of services). In the contract for services, the services are rendered under a contract for the provision of services between two separate enterprises so that the foreign enterprise may be taxable in the $\mathrm{SC}$ if it has a $\mathrm{PE}$ there to which the profits are attributable. By contrast, under the contract of services the services: (i) are rendered by an individual to an enterprise; and (ii) are in an employment relationship between the individual and the enterprise so that the employment article applies. ${ }^{147}$

A similar issue is found with regard to the business profits article vis-à-vis the directors' fees article and courts held that such latter provision applied to income earned as a working partner in a Belgian limited liability company. ${ }^{148}$ With regard to Art. $17 \S 1$ (taxation in the SC of income of foreign

144 Commentary to Art. 6 § $4-1$.

145 France, Conseil d'État, 12790, 30 May 1980, France, Conseil d'État, 37377-37378, 27 February 1984; France, Conseil d'État, 93187, 26 November 1975.

146 France, Conseil d'État, 349741, 5 April 2013.

147 Commentary to Art. $15 \S 8.4$.

148 Belgium, Hof van Beroep Gent, 2000-12-05, 5 December 2000; The Netherlands, Hoge Raad der Nederlanden, 35.242, 20 December 2000; Germany, Bundesfinanzhof, I R 106/09, 11 August 2010. 
entertainers and sportspersons in the absence of a $\mathrm{PE}$ ), the Commentary affirms that such provision is an exception to the rules in Art. $7^{149}$ so the question addressed by courts is how to determine the exact scope of this exception. ${ }^{150}$

1.109 Art. 7 (and not Art. 17) applies to payments for advertising or sponsorship income not attributed to performances or appearances ${ }^{151}$ and to other payments, such as payments received in the event of the cancellation of a performance, sponsorship/advertising fees not connected with performances, payments for merchandizing derived from sales in a country not connected with performances in that country, payments for image rights not connected with the entertainer's or sportsperson's performance, and payments for the broadcasting of a performance to the owner of the broadcasting rights. ${ }^{152}$ These payments for the broadcasting of a performance to the owner of the broadcasting rights occur for example when the organizer of a soccer tournament is also the owner of the broadcasting rights in the event and, as such, receives payments for broadcasting rights related to the event. The share of these payments, distributed by the owner of the broadcasting rights to participating teams, constitutes business profits for those recipients, provided that the payments are not re-distributed to the players. The payments for the broadcasting rights fall under Art. 7 because they are not related to personal activities of the performer and therefore do not constitute income derived by a person such as an entertainer or sportsperson from that person's personal activities as such. ${ }^{153}$

\section{PROTECTING THE PE OPERATION THROUGH THE NON-DISCRIMINATION CLAUSE}

1.110 When a PE is effectively existent in the $\mathrm{SC}$, the operation of such $\mathrm{PE}$ is protected by Art. $24 \S 3$ (the PE non-discrimination clause), which provides that the taxation on a $\mathrm{PE}$ which an enterprise of the $\mathrm{RC}$ has in the $\mathrm{SC}$ shall not be less-favourably levied in that $\mathrm{SC}$ than the taxation levied on enterprises of that SC carrying on the same activities. This treaty clause essentially establishes a full inbound equal treatment in the $\mathrm{SC}$ of $\mathrm{PEs}$ of

149 Commentary to Art. $17 \S 2$.

150 Czech Republic, Nejvyšší Správní Soud, 9 Afs 55/2007-76, 22 November 2007.

151 Commentary to Art. 17 § 9-4.

152 Commentary to Art. 17 \$ 9.4-1.

153 Commentary to Art. 17 § 9.4-1. 
foreign enterprises, but the Commentary enumerates derogations to such a clause and describes the actual implications of the same treatment clause for PEs.

The Commentary establishes full inbound equal treatment in the SC of PEs of foreign enterprises stating that Art. $24 \S 3$ is designed to end discrimination based on the actual situs of an enterprise in the $\mathrm{SC}$ that affects non-residents in the $\mathrm{SC}$ (i.e., residents of the $\mathrm{RC}$ ) who have a $\mathrm{PE}$ in the $\mathrm{SC}$ irrespective of their nationality. ${ }^{154}$ The Commentary however enumerates derogations to the full inbound equal treatment in the SC of PEs of foreign enterprises. First, specific or limited elements are relevant in establishing the comparable for inbound equal protection, for example, the head offices of the PEs and an enterprise in the SC to be comparable must have similar 'legal structure' or carry out the 'same activities'. Second, it is possible to have a different mode of taxation because the CS where the PE is situated (the SC) can limit/exclude personal allowances and reliefs. Third, the same treatment is not applicable to certain intra-group transactions, such as transfer prices.

The compared entities (i.e., the foreign head office of the PE and an 1.112 enterprise in the SC) first must belong to the same-sector business activities because the purpose of Art. $24 \S 3$ is to end all discrimination in the treatment of PEs as compared with resident enterprises belonging to the same sector of activities, as regards taxes based on business activities, and especially taxes on business profits. ${ }^{155}$ Second, the compared entities must have a similar legal structure', i.e., tax treatment in the $\mathrm{SC}$ of an enterprise of the $\mathrm{RC}$ should be compared to that of an enterprise of the SC that has a legal structure that is similar to that of the enterprise to which the PE belongs.

For example, Art. $24 \S 3$ does not require the $\mathrm{SC}$ to apply to the profits of the $\mathrm{PE}$ of an enterprise the same rate of tax as is applicable to a domestic enterprise in the SC. Third, the compared entities must carry out 'same activities'. The Commentary notes that regulated and unregulated activities generally do not constitute the 'same activities' for the purposes of Art. 24 § 3 , and that for purposes of Art. $24 \S 3$, a PE whose activities include the borrowing and lending of money is not entitled to the same treatment as domestic banks since the PE does not carry on the same activities. ${ }^{156}$

156 Commentary to Art. 24 § 38. See: Germany, Bundesfinanzhof, II R 51/03, 10 March 2005. 
1.114 The CS where PE is situated (the SC) can limit/exclude personal allowances and reliefs. Under Art. $24 \S 3$ it does not constitute discrimination ('more burdensome taxation') to tax non-resident persons differently, for practical reasons, from resident persons, as long as this does not result in more burdensome taxation for residents than for non-residents. ${ }^{157}$ Specific mechanisms or administrative practices that apply only for the purposes of determining profits attributable to a PE (Art. 7 § 2) do not per se violate Art. 24 $\S 3.158$

1.115 Art. $24 \S 3$ prevents dual use of allowances, but leaves it open to the SC to give personal allowances and reliefs to the persons concerned in the proportion which the amount of the PE's profits in the SC bears to the worldwide income taxable in the RC.159 It is also possible to limit incentives to PEs of non-resident taxpayers in the SC because they promote objectives directly related to the proper economic activity of the state concerned. Non-resident enterprises must meet the same requirements as resident enterprises and are not entitled to tax advantages attaching to activities the exercise of which is strictly reserved, on grounds of national interest, defence, protection of the national economy, etc. to domestic enterprises. ${ }^{160}$

1.116 The Commentary notes that the same treatment is not applicable to certain group transactions, such as rules that take account of the relationship between an enterprise and other enterprises (e.g., rules that allow consolidation, transfer of losses or tax-free transfers of property between companies under common ownership), or to the distribution of the profits of a resident enterprise, because those rules do not focus on the taxation of an enterprise's own business activities similar to those of the PE but, instead, focus on the taxation of a resident enterprise as part of a group of associated enterprises. ${ }^{161}$

1.117 The Commentary identifies the following areas of potential nondiscrimination of PEs versus domestic companies: deduction of the trading expenses, depreciation and reserves, loss carrying forward or backward, taxation of capital gains realized on the alienation of assets during or on the

157 Commentary to Art. 24 § 34.1 .

158 Commentary to Art. $24 \S 43.2$ and last statement. See: United States, US Court of Appeals for the Second Circuit, Reuters Ltd. v. New York Tax Appeals Tribunal, 12 October 1993, 603 N.Y.S.2d 795; Austria, Verfassungsgerichtshof (Constitutional Court), B758/88 - B759/88, 15 March 1990.

159 Commentary to Art. $24 \S 36$.

160 Commentary to Art. $24 \S 43$.

161 Commentary to Art. 24 § 41. See: Canada, Tax Court of Canada, Saipem UK Ltd. v. Her Majesty the Queen, 14 January 2011; Spain, Tribunal Supremo, 8720/1998, 12 April 2003. Commentary to Art. $24 \S 42$. See: Spain, Tribunal Supremo, 4517/1997, 15 July 2002. 
cessation of business. By contrast, equal treatment does not cover other sensitive areas. ${ }^{162}$

An issue addressed by national courts is whether the dividends received by a

$\mathrm{PE}$ in the $\mathrm{SC}$ in respect of participations owned by that $\mathrm{PE}$ in foreign companies, should be subject, in the same $\mathrm{SC}$, to the same treatment afforded to dividends received by domestic companies in the $\mathrm{SC}$ in respect of participations owned by those companies in foreign companies. ${ }^{163}$ The Commentary weighs the arguments for and against the extension of dividends exemption to PEs. ${ }^{164}$ An argument for the extension of dividends exemption to PEs is that the $\mathrm{PE}$ receiving dividends from the subsidiary should likewise be granted the exemption in view of the fact that a profits tax has already been levied in the hands of the subsidiary. This approach, mandated by the EU law, has also been adopted by national courts in respect of treaty issues. ${ }^{165}$ There are however arguments against the extension of the dividends exemption to PEs. The Commentary observes that assimilating PEs to local enterprises does not entail any obligation for the country where the PE is located to accord such special treatment to exempt received dividends. This argument has also been applied by national courts. ${ }^{166}$

Another issue concerning PEs of foreign companies is the withholding of tax on out-going dividends. The Commentary suggests adapting Art. $10 \S \S 2$ and 4 , so as to enable withholding tax to be levied in the $\mathrm{SC}$ on dividends paid by companies which are residents of the $\mathrm{SC}$ to $\mathrm{PEs}$ of companies which are residents of the $\mathrm{RC}$ the same way as if they were received directly, i.e., by the head offices of the RC companies. ${ }^{167}$

The $\mathrm{PE}$ is a part of a legal entity which is not under the jurisdiction of the

$\mathrm{SC}$, so if in applying the progressive scale, the SC takes into account the profits of the whole company to which such a $\mathrm{PE}$ belongs there can be a conflict with the PE non-discrimination article. So the Commentary suggests that a minimum tax rate for PEs can be accepted. ${ }^{168}$ Moreover, if a branch tax (a surcharge) is levied, then the profits of a $\mathrm{PE}$ of an enterprise of

162 Finland, Korkein Hallinto-oikeus, KHO:2013:169, 25 October 2013; Austria, Verwaltungsgerichtshof, 2005/14/0036, 16 February 2006; Switzerland, Bundesgericht/Tribunal fédéral, 2P.140/2005, 28 November 2005.

163 Gammie, Malcolm, 'Non Discrimination and the Taxation of Cross-Border Dividends', (2010) 2 World Tax. J. 162.

164 Commentary to Art. $24 \S \S 48-54$.

165 France, Conseil d'État, 50643, 18 November 1985.

166 Belgium, Hof van Cassatie/Cour de Cassation, F902F, 30 June 1988.

167 Commentary to Art. 24 § 64-66.

168 Commentary to Art. $24 \S 56$. 
the $\mathrm{RC}$ are taxed at a higher rate than the profits of enterprises of the SC. This is in theory contrary to Art. $24 \S 3$, but the justification of a branch tax is that if a subsidiary of the foreign enterprise earned the same profits as the $\mathrm{PE}$ and subsequently distributed these profits as dividends an additional withholding tax would be levied on these dividends in accordance with Art. $10 \S 2 .{ }^{169}$ Similarly, a 'branch level interest tax' is a tax imposed on amounts deducted, as interest, in computing the profits of a $\mathrm{PE}$, but such a tax is levied on the enterprise to which the interest is paid and therefore is not contrary to Art. $24 \S 3.170$

1.121 If foreign income (sourced in a third country) is included in profits attributable to a $\mathrm{PE}$ in the $\mathrm{SC}$ owned by a parent company in the RC, then Art. $24 \S 3$ requires that the $\mathrm{SC}$ grants to the $\mathrm{PE}$ the FTC on such income sourced in the third country if such FTC is granted to resident enterprises under domestic laws. ${ }^{171}$ The problem that arises in this situation is whether the FTC granted by the treaty between the SC and the third country can be extended to PEs in the SC of a taxpayer resident of the RC. ${ }^{172}$ The Commentary establishes that the same treatment should be extended to PEs in the SC that are recipients of dividends, interest, or royalties from a third country, attributing to them the FTC granted by the treaties concluded by the SC with such a third country.

1.122 The Commentary also focuses on the following situation: a PE in the SC of an enterprise resident of the $\mathrm{RC}$ receives dividends, interest or royalties from a third country and poses the following question: if and to what extent should the SC (where PE is situated) credit the tax that cannot be recovered from the third country? The Commentary takes the position that the FTC should be extended in those situations to the PE observing that the majority of countries grant credit in these cases on the basis of their domestic laws or under Art. $24 \S 3 .{ }^{173}$

1.123 National courts have addressed this problem but excluded the credit in the SC. ${ }^{174}$ The Commentary 2017 highlights that in these situations there can be triangular cases of abuses. For example, if a CS applies the exemption method of Art. 23A to the profits attributable to a PE situated in a third state which

169 Commentary to Art. $24 \S 60$.

170 Commentary to Art. $24 \S 61$. By contrast $\S \S 62-66$ observe that in respect of the withholding tax on dividends, interest and royalties received by a PE the CSs can include in the treaties specific provisions.

171 Commentary to Art. 24 §67. See: Belgium, Tribunal de Première Instance Bruxelles, 2007/63, Tijdschrift voor Fiscaal Recht, 2007; Germany, Finanzgericht Hamburg, II 69/80, 9 August 1985.

172 Commentary to Art. $24 \S 68$.

173 Commentary to Art. 24, § 70.1-4.

174 Belgium, Hof van Cassatie/Court de Cassation, RF 01718_1, 23 March 1995; Belgium, Hof van Cassatie/Court de Cassation, F930115F, 26 January 1995. 
does not tax passive income that arises in the other CS but that is attributable to such PE, there is risk that such income might not be taxed in any of the three states. Art. $29 \S 8$ addresses this issue. Moreover if the CS of which the enterprise is a resident exempts from tax the profits of the $\mathrm{PE}$ located in the other CS, there is a danger that the enterprise will transfer assets such as shares, bonds or patents to PEs in states that offer very favourable tax treatment, and in certain circumstances the resulting income may not be taxed in any of the three states. The Commentary suggests that to prevent such practices, a provision can be included in the convention between the state of which the enterprise is a resident and the third state (the state of source) stating that an enterprise can claim the benefits of the convention only if the income obtained by the PE situated in the other state is taxed normally in the state of the PE. ${ }^{175}$

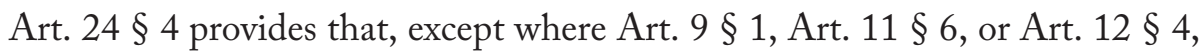
apply, interest, royalties and other disbursements paid by an enterprise of the $\mathrm{SC}$ to a resident of the $\mathrm{RC}$ shall, for the purpose of determining the taxable profits of such an enterprise, be deductible under the same conditions as if they had been paid to a resident of the SC. Similarly, any debts of an enterprise of the $\mathrm{SC}$ to a resident of the $\mathrm{RC}$ shall, for the purpose of determining the taxable capital of such an enterprise, be deductible under the same conditions as if they had been contracted to a resident of the SC.

This treaty clause essentially establishes a full inbound equal treatment in the $\mathrm{SC}$ of foreign and domestic enterprises, but the Commentary enumerates derogations in respect to thin cap issues: the country of the borrower can apply its domestic rules on thin cap in so far as these are compatible with arm's length (Art. $9 \S 1$ Art. $11 \S 6$ or Art $12 \S 4$ ), while limitations of deductions which only apply to non-resident creditors (to the exclusion of resident creditors) are prohibited. ${ }^{176}$ The Commentary takes the position that payments of interest to resident/non-resident taxpayers under thin cap rules are outside the scope of Art. $24 \S 5 .{ }^{177}$ National courts have taken differing views:

175 Commentary to Art. 24, §§ 7-72.

176 Commentary to Art. $24 \$ 73-74$. See: Nakhai, Katja, et al., 'Thin Capitalization Rules and Nondiscrimination Principles' (2004) 32 Intertax 126; Gouthiere, Bruno, 'Thin Capitalization Rules and the Non-discrimination Principle' (2002) 42 Eur. Tax, 159; IFA, 'International Aspects of Thin Capitalization', (1996) 81b Cabiers Droit Fisc. Intl.

177 Commentary to Art. $24 \S 79.2$. 
a judicial approach bars thin cap rules that adversely ring fence foreign lenders, while an opposing approach protects domestic thin cap rules as anti-abuse rules. ${ }^{178}$

178 Spain, Tribunal Supremo, 5871/2006, 17 March 2011; Germany, Bundesfinanzhof, I R 6/09, 8 September 2010; France, Conseil d'État, 233894, 14 November 2001; France, Court Administrative d'Appel Nancy, 98-1741, 10 October 2002; Spain, Tribunal Económico Administrativo Central, 2335/2002; Spain, Tribunal Económico Administrativo Central, 2007-12-20, 20 December 2007; Canada, Tax Court of Canada, Ramada Ontario Ltd. v. Her Majesty the Queen, 3 December 1993. 